\title{
Data report: permeability, consolidation, stress state, and pore system characteristics of sediments from Sites C0011, C0012, and C0018 of the Nankai Trough'
}

\author{
Hugh Daigle ${ }^{2,3}$ and Brandon Dugan ${ }^{2}$
}

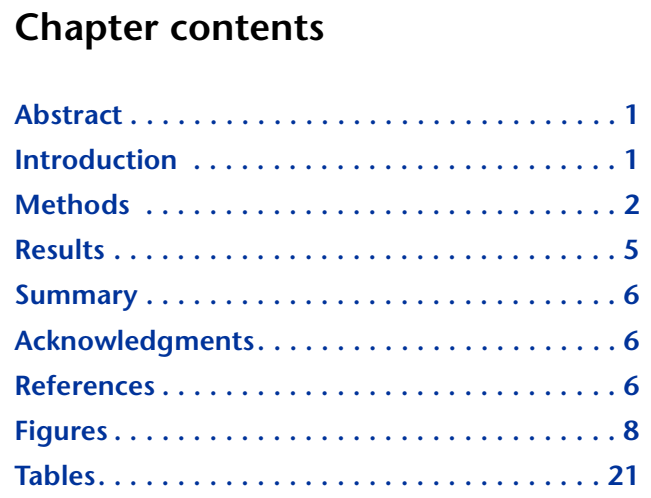

'Daigle, H., and Dugan, B., 2014. Data report: permeability, consolidation, stress state, and pore system characteristics of sediments from Sites C0011, C0012, and C0018 of the Nankai Trough. In Henry, P., Kanamatsu, T., Moe, K., and the Expedition 333 Scientists, Proc. IODP, 333: Tokyo (Integrated Ocean Drilling Program Management International, Inc.).

doi:10.2204/iodp.proc.333.201.2014

${ }^{2}$ Department of Earth Science, Rice University, 6100 Main Street, Houston TX 77005, USA. Correspondence author: daigle@austin.utexas.edu

${ }^{3}$ Also at: Department of Petroleum and Geosystems Engineering, The University of Texas at Austin, 200 E Dean Keeton Street, Stop C0300, Austin TX 78712-1585, USA.

\begin{abstract}
We performed uniaxial, constant-rate-of-strain consolidation experiments; grain size analyses; specific surface measurements; and mercury injection capillary pressure (MICP) measurements to characterize transport and deformation properties of 30 specimens from Integrated Ocean Drilling Program Expedition 333 Sites C0011, C0012, and C0018. Permeability, compression index, and overconsolidation ratio were determined from consolidation experiments. Permeability values range from $2.3 \times 10^{-14} \mathrm{~m}^{2}$ to 5.9 $\times 10^{-19} \mathrm{~m}^{2}$ and generally decrease with increasing depth. Compression indexes, which define stress-strain behavior during consolidation, range from 0.26 to 2.7. Overconsolidation ratios, defined as the ratio of the preconsolidation stress to the in situ vertical effective stress under hydrostatic conditions, range from 0.20 to 4.1 and generally decrease with increasing depth. Median grain sizes determined by Stokes settling analysis range from 1.10 to $15.4 \mu \mathrm{m}$, and samples consist mainly of silt- and clay-sized particles. Specific surface values determined by methylene blue adsorption range from 25.7 to $77.7 \mathrm{~m}^{2} / \mathrm{g}$. MICP measurements on a subset of 14 samples yield median pore throat radii of 0.087 to $0.36 \mu \mathrm{m}$ and air-water capillary entry pressure values of 64 to 770 $\mathrm{kPa}$.
\end{abstract}

\section{Introduction}

Integrated Ocean Drilling Program (IODP) Expedition 333 was conducted to sample previously uncored intervals from Sites C0011 and C0012 and to drill and core Site C0018 to constrain submarine landslide history along the lower forearc slope in the vicinity of the seafloor outcrop of the megasplay fault of the Nankai subduction zone (Henry et al., 2010) (Fig. F1). This expedition was part of the larger Nankai Trough Seismogenic Zone Experiment (NanTroSEIZE), the goals of which were understanding faulting, deformation, and hydrological processes in the vicinity of the plate boundary and megasplay faults along the Nankai convergent margin (Tobin and Kinoshita, 2006).

We performed laboratory analyses of consolidation and fluid transport characteristics with the goal of constraining physical properties that influence sediment deformation and heat and fluid flow within the Nankai accretionary complex. This work complements other shore-based laboratory and modeling efforts 
by characterizing the physical properties of the input material to the subduction zone and helps us understand how the sediments change through time as they are subducted. We used whole-round samples for constant-rate-of-strain (CRS) consolidation experiments to determine permeability, compression index, and overconsolidation ratio (OCR). Sample trimmings from CRS specimens were used for grain size, specific surface, and mercury injection capillary pressure (MICP) measurements to compare with geotechnical properties and ultimately to understand the pore-scale controls on hydrologic properties of sediments in the accretionary margin. Our work complements other geotechnical and sedimentological work that is ongoing throughout the NanTroSEIZE project. Integration of these studies across the lifetime of the project will result in a complete data set of geotechnical and sedimentological parameters that may be used to understand interactions and feedback among sediment physical properties, hydrologic processes, and deformation within the Nankai convergent margin.

\section{Methods}

Whole-round samples were sealed and stored at $4^{\circ} \mathrm{C}$ to minimize water loss prior to testing. Shipboard selection of whole-round specimens was conducted by D/V Chikyu staff based on visual inspection and analysis of X-ray computed tomography (CT) images to identify areas free of cracks and voids and with minimal (no visual) coring disturbance. Material for grain size and MICP measurements was taken immediately adjacent to samples used for geotechnical tests to ensure data consistency.

\section{Constant-rate-of-strain consolidation tests}

CRS consolidation tests were performed at room temperature $\left(20^{\circ} \mathrm{C}\right)$ with consolidation in the vertical direction (parallel to the $z$-axis of the core), except for Sample 333-C0012E-3X-4, 31.5-37.5 cm, with which we performed an additional consolidation test normal to the $z$-axis of the core (i.e., in the horizontal direction). These tests were performed following American Society for Testing and Materials (ASTM) International standards (ASTM International, 2006). Samples were extruded from the core liner and trimmed into a fixed metal ring using a trimming jig, wire saw, sharp-edged spatula, and recess tool. This ensured that all samples had a height of $2.41 \mathrm{~cm}$ and diameter of $5.09 \mathrm{~cm}$ prior to testing. After trimming, the sample and fixed ring were loaded into the consolidation chamber with porous stones and filter paper on the top and base of the sample. The use of the fixed ring ensured zero lateral strain during consolidation. The consolidation chamber was sealed, filled with distilled water, and pressurized with a constant pressure of $386 \mathrm{kPa}$ overnight $(>8 \mathrm{~h})$ to ensure complete saturation of the sample. Following this saturation stage, the drain valve at the base of the sample was locked and the sample was consolidated vertically at a constant strain rate $(\dot{\varepsilon})$. During consolidation, the pore pressure ratio (ratio of difference between the pressure at the base of the sample and chamber pressure to the chamber pressure) was monitored, and $\dot{\varepsilon}$ was adjusted between $0.2 \%$ and $0.5 \% / \mathrm{h}$ to maintain a pore pressure ratio $<0.15$. During the test, the total axial stress $\left(\sigma_{a}\right)$, instantaneous sample height $(H)$, and pore pressure at the base of the sample $\left(P_{\mathrm{p}}\right)$ were recorded. Each test proceeded until $20 \%$ axial strain to ensure a suitable amount of virgin consolidation data (consolidation at vertical effective stress greater than the past maximum effective stress of the sample; we assume the past maximum effective stress equals the preconsolidation stress).

Data recorded during each consolidation test were used to determine compression index $\left(C_{c}\right)$, permeability $(k)$, preconsolidation stress $\left(\sigma_{\mathrm{pc}}{ }^{\prime}\right)$, and OCR. $C_{\mathrm{c}}$ defines the stress-strain relationship during virgin consolidation (Craig, 1992) (Fig. F2) and was computed as

$$
C_{\mathrm{c}}=\left(e_{\sigma \mathrm{a}^{\prime}}-e_{\sigma \mathrm{a}^{\prime}+\Delta \sigma \mathrm{a}^{\prime}}\right) /\left[\log \left(\sigma_{\mathrm{a}}{ }^{\prime}-\Delta \sigma_{\mathrm{a}}{ }^{\prime} / \sigma_{\mathrm{a}}{ }^{\prime}\right)\right],
$$

where

$$
\begin{aligned}
C_{\mathrm{c}} & =\text { compression index } \\
e & =\text { void ratio, and } \\
\sigma_{\mathrm{a}}{ }^{\prime} & =\text { axial effective stress }(\mathrm{Pa}) .
\end{aligned}
$$

Void ratio during the consolidation test was determined from strain data and the initial void ratio at laboratory conditions, which was computed from mass and density measurements following the method of Blum (1997). Permeability was computed as

$$
k=\left(\dot{\varepsilon} H H_{0} \mu\right) /(2 \Delta u),
$$

where

$$
\begin{aligned}
k & =\text { permeability }\left(\mathrm{m}^{2}\right), \\
\dot{\varepsilon} & =\text { strain rate }(1 / \mathrm{s}), \\
H & =\text { specimen height }(\mathrm{m}) \\
H_{0} & =\text { instantaneous specimen height }(\mathrm{m}), \\
\mu & =\text { dynamic viscosity of pore fluid }(\mathrm{Pa} \cdot \mathrm{s}), \text { and } \\
\Delta u & =\text { base excess pressure }(\mathrm{Pa}) .
\end{aligned}
$$

We assumed a pore fluid dynamic viscosity of 0.001 $\mathrm{Pa} \cdot \mathrm{s}$. Base excess pressure is defined as the difference between the pore pressure at the base of the specimen $\left(P_{\mathrm{p}}\right)$ and the consolidation cell pressure $\left(P_{c}\right)(\Delta u$ 
$\left.=P_{\mathrm{p}}-P_{\mathrm{c}}\right)$. Base excess pressure data were smoothed using a three-point moving average, and strain rate data were smoothed using a six-point moving average. Permeability was extrapolated to initial permeability $\left(k_{0}\right)$ at the initial porosity for each specimen by assuming a log-linear relationship between porosity and permeability during virgin consolidation (e.g., Neuzil, 1994) (Fig. F3).

Permeability and axial effective stress data were used to determine the coefficient of consolidation $\left(c_{\mathrm{v}}\right)$ during each test (ASTM International, 2006; Craig, 1992):

$$
c_{\mathrm{v}}=k / \mu m_{\mathrm{v}}
$$

where

$$
\begin{aligned}
& c_{\mathrm{v}}=\text { coefficient of consolidation }\left(\mathrm{m}^{2} / \mathrm{s}\right), \\
& k=\text { permeability }\left(\mathrm{m}^{2}\right), \\
& \mu=\text { dynamic viscosity of pore fluid }(\mathrm{Pa} \cdot \mathrm{s}), \text { and } \\
& m_{\mathrm{v}}=\text { coefficient of volume compressibility }(1 / \mathrm{Pa}) .
\end{aligned}
$$

The coefficient of volume compressibility $\left(m_{v}\right)$ is defined as the change in axial strain per unit increase in axial effective stress (Craig, 1992) and is computed as

$$
m_{\mathrm{v}}=\left(\varepsilon_{\sigma a^{\prime}+\Delta \sigma a^{\prime}}-\varepsilon_{\sigma a^{\prime}}\right) /\left[\left(\sigma_{a}{ }^{\prime}+\Delta \sigma_{a}{ }^{\prime}\right)-\sigma_{a}{ }^{\prime}\right],
$$

where $\varepsilon=$ axial strain.

Preconsolidation stress $\left(\sigma_{\mathrm{pc}}{ }^{\prime}\right)$ was determined for all samples except the horizontally oriented measurement on Sample 333-C0012E-3X-4, 31.5-37.5 cm. $\sigma_{\mathrm{pc}}{ }^{\prime}$ represents an estimate of the maximum vertical effective stress that a sample has experienced. We determined $\sigma_{\mathrm{pc}}{ }^{\prime}$ using the work-stress method of Becker et al. (1987). This method analyzes the slope of the preyield and postyield behavior of the sample in axial stress-work per unit volume space (Fig. F4). The work per unit volume $(\Delta W)$ resulting from an incremental increase in axial stress was computed by

$$
\Delta W=\left\{\left[\sigma_{a}{ }^{\prime}+\left(\sigma_{a}{ }^{\prime}+\Delta \sigma_{a}{ }^{\prime}\right)\right] / 2\right\} \times\left(\varepsilon_{\sigma a^{\prime}+\Delta \sigma a^{\prime}}-\varepsilon_{\sigma a^{\prime}}\right)
$$

where $W=$ work per unit volume $\left(\mathrm{J} / \mathrm{m}^{3}\right)$.

This defines $\sigma_{p c}$ for each specimen. Sample disturbance can result in a poorly defined $\sigma_{\mathrm{pc}}{ }^{\prime}$ (Santagata and Germaine, 2002). See Saffer (2003) and Dugan and Germaine (2008) for further discussion of errors associated with interpretation of $\sigma_{p c}{ }^{\prime}$. OCR is the ratio of $\sigma_{p c}{ }^{\prime}$ to the hydrostatic vertical effective stress $\left(\sigma_{\mathrm{vh}}{ }^{\prime}\right) . \sigma_{\mathrm{vh}}{ }^{\prime}$ is determined as the difference between the total vertical stress and the hydrostatic fluid pressure and was determined for each vertically oriented specimen from shipboard moisture and density (MAD) data:

$$
\sigma_{v h}^{\prime}(z)=g \int_{0}^{z} \rho_{b}(\zeta) d \zeta-\rho_{w} \mathrm{gz},
$$

where

$$
\begin{aligned}
& \rho_{\mathrm{b}}=\text { bulk density from MAD data }\left(\mathrm{kg} / \mathrm{m}^{3}\right), \\
& \rho_{\mathrm{w}}=\text { pore fluid (water) density }\left(\mathrm{kg} / \mathrm{m}^{3}\right), \\
& \mathrm{g}=\text { acceleration due to gravity }\left(\mathrm{m} / \mathrm{s}^{2}\right) \\
& \zeta=\text { constant of integration }(\mathrm{m}), \text { and } \\
& Z=\text { depth below seafloor }(\mathrm{m}) .
\end{aligned}
$$

We assumed $\rho_{w}=1024 \mathrm{~kg} / \mathrm{m}^{3}$. The first term on the right-hand side of Equation 6 is the total vertical stress, and the second term is the hydrostatic fluid pressure. The estimated in situ vertical effective stress from Equation 6 and the preconsolidation stress from the work-stress analysis were used to determine OCR. An OCR $>1$ suggests that the sample has been unloaded from a previous greater hydrostatic vertical effective stress, and an OCR $<1$ suggests in situ overpressure conditions. Cements or other diagenetic mineralization may result in an OCR $>1$ because of enhanced sediment strength (e.g., Morgan et al., 2007). An OCR = 1 is interpreted to represent that the specimen was at its greatest hydrostatic vertical effective stress at in situ conditions.

\section{Grain size measurements}

Grain size measurements were conducted following the ASTM standard for particle size analysis (ASTM International, 2007). All measurements were conducted by hydrometer analysis in a settling column, as no particles were retained by passing through a 2 $\mathrm{mm}$ sieve. Samples were oven-dried at $105^{\circ} \mathrm{C}$ for at least $24 \mathrm{~h}$ and powdered with a ceramic mortar and pestle. The powdered samples were then mixed with distilled water and $5 \mathrm{~g}$ of sodium hexametaphosphate dispersant and left to soak overnight ( $>16 \mathrm{~h}$ ). After soaking, the samples were further dispersed for 1 min using a Hamilton Beach milkshake mixer, poured into a settling column, and diluted with distilled water to make $1 \mathrm{~L}$ of solution. The column was then agitated for $1 \mathrm{~min}$ and left to settle. During settling, measurements of the bulk density of the solution were made periodically using ASTM hydrometer $151 \mathrm{H}$. The mass fraction of particles remaining in suspension $\left(m_{\mathrm{p}}\right)$ at the time of measurement is given by

$$
m_{\mathrm{p}}=\left[\rho_{\mathrm{s}} V\left(\rho-\rho_{\mathrm{f}}\right)\right] /\left[\left(\rho_{\mathrm{s}}-1000\right) m_{\mathrm{s}}\right]
$$

where

$$
\begin{aligned}
m_{\mathrm{p}}= & \text { mass fraction of particles remaining in sus- } \\
& \text { pension, } \\
\rho_{\mathrm{s}}= & \text { specimen grain density (taken as } 2700 \mathrm{~kg} / \\
& \left.\mathrm{m}^{3}\right), \\
V= & \text { volume of solution }\left(\mathrm{m}^{3}\right),
\end{aligned}
$$


$m_{\mathrm{s}}=$ dry mass of specimen $(\mathrm{kg})$,

$\rho=$ hydrometer reading $\left(\mathrm{kg} / \mathrm{m}^{3}\right)$, and

$\rho_{\mathrm{f}}=$ density of solution fluid without sediment $\left(\mathrm{kg} / \mathrm{m}^{3}\right)$.

The particle diameter $(D)$ corresponding to a mass fraction of particles obtained from Equation 7 is given by

$$
D=\sqrt{\frac{30 \mu L}{t\left(\rho_{s}-1000\right) g}},
$$

where

$D=$ equivalent particle diameter $(\mathrm{m})$,

$\mu=$ solution fluid viscosity (Pa.s),

$L=$ effective depth from solution surface to center of hydrometer bulb (m),

$t=$ time of hydrometer measurement (s), and

$\mathrm{g}=$ acceleration due to gravity $\left(\mathrm{m} / \mathrm{s}^{2}\right)$.

$L$ was determined for hydrometer $151 \mathrm{H}$ from Table 2 of the ASTM standard (ASTM International, 2003).

\section{Specific surface measurements}

Specific surface measurements were conducted by methylene blue adsorption using the spot-test method (Santamarina et al., 2002). Samples were oven-dried at $60^{\circ} \mathrm{C}$ for at least $72 \mathrm{~h}$ to allow evaporation of pore water but prevent any clay alteration. Following drying, samples were powdered with a ceramic mortar and pestle. During measurement, $10 \mathrm{~g}$ of powdered sediment was mixed with a solution of $1 \mathrm{~g}$ methylene blue powder $\left(\mathrm{C}_{16} \mathrm{H}_{18} \mathrm{ClN}_{3} \mathrm{~S}\right)$ and 200 $\mathrm{mL}$ distilled water in $0.5 \mathrm{~mL}$ increments dispensed by pipette. The mixture was stirred continuously with a magnetic stirrer throughout the measurement process. After stirring for $1 \mathrm{~min}$ following addition of a methylene blue solution increment, a sample of the mixture was taken by eyedropper and a drop placed on Fisher brand filter paper P5. When all mineral surfaces are coated with methylene blue, the excess methylene blue in solution will bleed out around the drop on the filter paper and form a halo around the drop. When a halo was observed, the measurement process was deemed complete. The specific surface $\left(S_{\mathrm{a}}\right)$ is given by

$$
S_{\mathrm{a}}=\left(1 / \mathrm{M}_{\mathrm{m}}\right)(1 / 200) 0.5 \mathrm{NA}_{\mathrm{v}} A_{\mathrm{MB}}(1 / 10) \text {, }
$$

where

$S_{\mathrm{a}}=$ specific surface $\left(\mathrm{m}^{2} / \mathrm{g}\right)$,

$\mathrm{M}_{\mathrm{m}}=$ molar mass of methylene blue $(319.87 \mathrm{~g} / \mathrm{mol})$,

$N$ = number of methylene blue increments,

$A_{v}=$ Avogadro's number $(1 / \mathrm{mol})$, and

$A_{\mathrm{MB}}=$ mineral surface area covered by one molecule of methylene blue $\left(1.3 \times 10^{-18} \mathrm{~m}^{2}\right)$.
Because methylene blue adsorption is performed on wet samples, the measured surface area includes the surfaces within clay interlayers (Santamarina et al., 2002).

\section{Mercury injection capillary pressure measurements}

MICP measurements were performed at room temperature $\left(20^{\circ} \mathrm{C}\right)$ using a Micrometrics AutoPore device. Prior to measurement, samples were oven-dried at $115^{\circ} \mathrm{C}$ for at least $24 \mathrm{~h}$. During the measurement, each sample was immersed in mercury within a pressure-sealed chamber, which was attached to a capillary stem with a cylindrical coaxial capacitor. The mercury pressure was increased incrementally to a maximum of $380 \mathrm{MPa}$, and each pressure step was held until volume equilibrium was reached as determined from the change in the capacitance of the system. The volume of mercury injected at each increment was determined by capacitance measurements. Pore volume was computed from the bulk sample volume determined by immersion in mercury, and porosity was determined following the method of Blum (1997).

The volume of mercury injected at each pressure increment was used along with pore volume and pressure data to construct a pore size distribution for each sample. Mercury injection pressure $\left(P_{\mathrm{Hg}}\right)$ was converted to pore radius $\left(r_{\mathrm{p}}\right)$ using the Young-Laplace equation:

$$
r_{\mathrm{p}}=2 \sigma_{\mathrm{Hg}} \cos \theta_{\mathrm{Hg}} / P_{\mathrm{Hg}}
$$

where

$r_{\mathrm{p}}=$ pore radius $(\mathrm{m})$

$\sigma_{\mathrm{Hg}}=$ air-mercury interfacial tension $(0.485 \mathrm{~N} / \mathrm{m})$,

$\theta_{\mathrm{Hg}}=$ mercury-sediment contact angle $\left(140^{\circ}\right)$, and

$P_{\mathrm{Hg}}=$ mercury injection pressure $(\mathrm{Pa})$.

The median pore radius $\left(r_{50}\right)$ was determined as the median of the pore size distribution.

Mercury injection pressure $\left(P_{\mathrm{Hg}}\right)$ was converted to air-water capillary pressure $\left(P_{c}\right)$ by

$$
P_{\mathrm{c}}=\left(\sigma_{\mathrm{aw}} \cos \theta_{\mathrm{aw}} / \sigma_{\mathrm{Hg}} \cos \theta_{\mathrm{Hg}}\right) P_{\mathrm{Hg}}
$$

where

$P_{\mathrm{c}}=$ air-water capillary pressure $(\mathrm{Pa})$,

$\sigma_{\mathrm{aw}}=$ air-water interfacial tension $(0.072 \mathrm{~N} / \mathrm{m})$,

$\theta_{\mathrm{aw}}=$ air-water contact angle $\left(180^{\circ}\right)$, and

$P_{\mathrm{Hg}}=$ mercury injection pressure $(\mathrm{Pa})$.

Air-water entry pressure was determined from the minimum mercury injection pressure at which the volume of injected mercury was nonzero. This corre- 
sponds to the mercury percolation threshold (Bear, 1972).

\section{Results}

All nomenclature is provided in Table T1. Consolidation, grain size, and specific surface data are summarized in Table T2. MICP data are summarized in Table T3. Complete experiment data for consolidation (333_CONSOL), grain size (333_GRAIN_SIZE), and MICP (333_MICP) are provided in "Supplementary material."

Porosity values determined in the laboratory are shown in Figure F5 along with shipboard MAD results. The laboratory values agree well with the MAD values. However, neither the laboratory nor the MAD porosity values were corrected for smectite content. Smectite contains significant volumes of interlayer water, and uncorrected porosity may overestimate the volume of intergranular porosity available for fluid flow. Gamage et al. (2011) showed that smectite corrections in Nankai sediments can decrease porosity by roughly half. Deeper samples from Sites C0011 and C0012 have smectite contents of 31-55 wt\% (Underwood and Guo, 2013), which correspond to interlayer water mass fractions of roughly $6-11 \mathrm{wt} \%$ assuming clay interlayer spacing of $1.5 \mathrm{~nm}$ (Gamage et al., 2011). Detailed clay mineralogy information on the samples we measured would make this correction possible. The results we present here, as well as the shipboard MAD values, therefore represent an upper limit of the true intergranular porosity. Laboratory measurements are plotted against depth in Figures F6, F7, and F8. The depth reference is meters core depth below seafloor (CSF-B), which corrects the core depth for expansion in cases where core recovery exceeds 100\% (see IODP Depth Scales Terminology v.2 at www.iodp.org/program-policies/procedures/guidelines/). Permeabilities $\left(k_{0}\right)$ interpreted from CRS consolidation experiments for Sites C0011, C0012, and C0018 range from $2.3 \times 10^{-14}$ $\mathrm{m}^{2}$ to $5.9 \times 10^{-19} \mathrm{~m}^{2}$ and generally decrease with increasing depth (Table T2; Figs. F6A, F7A, F8A). Compression indexes $\left(C_{c}\right)$ range from 0.26 to 2.7 and decrease with increasing depth, except at Site C0011, where the highest values are encountered between 90 and 200 m CSF-B (Table T2; Figs. F6B, F7B, F8B). The general decrease in $C_{c}$ with depth is consistent with established trends of decreasing $C_{c}$ with decreasing porosity (e.g., Long et al., 2011). This trend is reversed, however, in lithologic Subunit IA at Sites C0011 and C0012, and the depth interval of this reverse trend corresponds with the depth interval of anomalously high porosity at these sites (see the "Site C0011" and "Site C0012" and "Expedition
333 summary" chapters [Expedition 333 Scientists, 2012a, 2012b, 2012c]). OCRs range from 0.20 to 4.1 and generally decrease with depth, with a few exceptions at Sites C0011 and C0018 (Table T2; Figs. F6C, F7C, F8C). The three samples from Mass Transport Deposit (MTD) 6 at Site C0018 show an increase in OCR toward the base of the MTD, which is consistent with observations of shearing-induced consolidation in MTDs (e.g., Dugan, 2012). The CRS consolidation tests performed on Sample 333-C0012E-3X$4,31.5-37.5 \mathrm{~cm}$, perpendicular to the borehole axis (i.e., horizontal) yielded permeability 56 times higher than the vertical permeability and a similar value of $C_{\mathrm{c}}$ (Table T2).

Specific surface $\left(S_{\mathrm{a}}\right)$ values range from 25.7 to 77.7 $\mathrm{m}^{2} / \mathrm{g}$ (Table T2; Figs. F6D, F7D, F8D). $S_{\mathrm{a}}$ generally increases with depth within Subunit IA at all sites. Median grain size $\left(D_{50}\right)$ ranges from 1.10 to $15.4 \mu \mathrm{m}$, and samples are dominated by silt- and clay-sized particles, with silt-sized particles comprising $32.3 \%$ to $67.1 \%$ of all samples by mass (Table T2; Figs. F6E, F7E, F8E). Clay-sized particles account for $22.5 \%$ to $67.7 \%$ of all samples by mass (Table T2; Figs. F6F, F7F, F8F). The only sample with $>10 \%$ sand-sized particles by mass is located at $222.28 \mathrm{~m}$ CSF-B in Hole C0018A. For spherical grains, $S_{\mathrm{a}}$ is inversely proportional to grain size (Santamarina et al., 2002). Our $S_{\mathrm{a}}$ values show little correlation with grain size (Fig. F9), except for one sample from Site C0018 which has low $S_{\mathrm{a}}$ and relatively high $D_{50}$. This overall lack of apparent trend may be due to the narrow range of $D_{50}$ present in these data.

Median pore radii $\left(r_{50}\right)$ interpreted from MICP measurements range from 0.087 to $0.36 \mu \mathrm{m}$, and air-water capillary entry pressures $\left(P_{\mathrm{c}}\right)$ range from 64 to 770 kPa (Table T3; Figs. F10A, F10B, F11A, F11B, F12A, F12B). Although consolidation would be expected to reduce pore sizes and increase capillary entry pressure (e.g., Dewhurst et al., 1999), neither $r_{50}$ nor $P_{c}$ exhibit any consistent trends with depth across the three sites. The samples from MTD 6 at Site C0018 exhibit a general decrease in $r_{50}$ and increase in $P_{\mathrm{c}}$ with increasing depth within the MTD (Fig. F12A, F12B). Hydraulic radius theories of permeability predict a power-law relationship between permeability and pore size (Dullien, 1992), and from Equation 9 there should be a corresponding power-law relationship between permeability and $P_{\mathrm{c}}$. The data from Site C0011 show such trends (Fig. F10A, F10B), but the relationships at Sites $\mathrm{C} 0012$ and $\mathrm{C} 0018$ are more complicated (Figs. F11A, F11B, F12A, F12B).

Our results were determined at laboratory conditions and are therefore subject to sample disturbance during coring and during experimental preparation 
in the laboratory. Visual inspection of samples prior to trimming the CRS consolidation tests did not reveal any flaws in the samples, which was consistent with the shipboard sampling procedure of selecting intervals free of cracks or voids based on CT images. However, several samples were computed to have an OCR $<1$, suggesting underconsolidation. Underconsolidation may be associated with in situ fluid pressure in excess of hydrostatic pressure (e.g., Long et al., 2008), and this may be the cause of the low OCR for Sample 333-C0018A-16H-2, 40-45 cm, which experienced expansion in the core barrel (see the "Site C0018" and "Expedition 333 summary" chapters [Expedition 333 Scientists, 2012d, 2012a]) and was difficult to remove from the liner in the laboratory. However, the other OCR values $<1$ are associated with extended punch coring system (EPCS) and extended shoe coring system (ESCS) cores, which were noted to return poorer quality cores than the hydraulic piston coring system (HPCS) (see the "Site C0018" chapter [Expedition 333 Scientists, 2012d]). Coring disturbance erases some of the original stress history from samples and causes yield to virgin consolidation at lower effective stresses (La Rochelle et al., 1981) and therefore results in low OCR values. This probably affected some of the deeper samples from Sites C0011 and C0018.

\section{Summary}

We characterized transport and deformation properties from Sites C0011, C0012, and C0018 with CRS consolidation experiments, grain size analyses, specific surface measurements, and MICP measurements. Permeability values are mostly $<10^{-15} \mathrm{~m}^{2}$ and generally decrease with increasing depth. Compression indexes, which define stress-strain behavior during consolidation, range from 0.26 to 2.7. Overconsolidation ratios range from 0.20 to 4.1 and generally decrease with increasing depth. Median grain sizes range from 1.1 to $15.4 \mu \mathrm{m}$, and samples consist mainly of silt- and clay-sized particles. Specific surface values range from 25.7 to $77.7 \mathrm{~m}^{2} / \mathrm{g}$. MICP measurements yield median pore throat radii of 0.087 to $0.36 \mu \mathrm{m}$ and air-water capillary entry pressure values of 0.064 to $0.77 \mathrm{MPa}$.

\section{Acknowledgments}

Samples and data were provided by the Integrated Ocean Drilling Program (IODP). Funding was provided by a postexpedition award from the Consortium for Ocean Leadership. The authors thank the science party and technical staff of IODP Expedition 333 , whose efforts made this work possible. MICP measurements were performed by Core Laboratories in Houston, Texas (USA).

\section{References}

ASTM International, 2003. Standard test method for particle-size analysis of soils (Standard D422-63[2002]). In Annual Book of ASTM Standards (Vol. 04.08): Soil and Rock (I): West Conshohocken, PA (Am. Soc. Testing Mater.), 10-17. http://www.astm.org/DATABASE.CART/HISTORICAL/D422-63R02.htm

ASTM International, 2006. Standard test method for onedimensional consolidation properties of saturated cohesive soils using controlled-strain loading (Standard D4186-06). In Annual Book of ASTM Standards (Vol. 04.08): Soil and Rock (I): West Conshohocken, PA (Am. Soc. Testing Mater.) http://www.astm.org/DATABASE.CART/HISTORICAL/D4186-06.htm

ASTM International, 2007. Standard test method for particle-size analysis of soils (Standard D422-63[2007]). In Annual Book of ASTM Standards (Vol. 04.08): Soil and Rock (I): West Conshohocken, PA (Am. So. Testing Mater.). doi:10.1520/D0422-63R07

Bear, J., 1972. Dynamics of Fluids in Porous Media: New York (Elsevier).

Becker, D.E., Crooks, J.H.A., Been, K., and Jeffries, M.G., 1987. Work as a criterion for determining in situ and yield stresses in clays. Can. Geotech. J., 24(4):549-564. doi:10.1139/t87-070

Blum, P., 1997. Physical properties handbook: a guide to the shipboard measurement of physical properties of deep-sea cores. ODP Tech. Note, 26. doi:10.2973/ odp.tn.26.1997

Craig, R.F., 1992. Soil Mechanics (5th ed.): London (Chapman and Hall).

Dewhurst, D.N., Aplin, A.C., and Sarda, J.-P., 1999. Influence of clay fraction on pore-scale properties and hydraulic conductivity of experimentally compacted mudstones. J. Geophys. Res.: Solid Earth, 104(B12):29261-29274. doi:10.1029/1999JB900276

Dugan, B., 2012. Petrophysical and consolidation behavior of mass transport deposits from the northern Gulf of Mexico, IODP Expedition 308. Mar. Geol., 315-318:98107. doi:10.1016/j.margeo.2012.05.001

Dugan, B., and Germaine, J.T., 2008. Near-seafloor overpressure in the deepwater Mississippi Canyon, northern Gulf of Mexico. Geophys. Res. Lett., 35(2):L02304. doi:10.1029/2007GL032275

Dullien, F.A.L., 1992. Porous Media: Fluid Transport and Pore Structure: San Diego (Academic Press).

Expedition 333 Scientists, 2012a. Expedition 333 summary. In Henry, P., Kanamatsu, T., Moe, K., and the Expedition 333 Scientists, Proc. IODP, 333: Tokyo (Integrated Ocean Drilling Program Management International, Inc.). doi:10.2204/iodp.proc.333.101.2012

Expedition 333 Scientists, 2012b. Site C0011. In Henry, P., Kanamatsu, T., Moe, K., and the Expedition 333 Scientists, Proc. IODP, 333: Tokyo (Integrated Ocean Drilling 
Program Management International, Inc.). doi:10.2204/iodp.proc.333.104.2012

Expedition 333 Scientists, 2012c. Site C0012. In Henry, P., Kanamatsu, T., Moe, K., and the Expedition 333 Scientists, Proc. IODP, 333: Tokyo (Integrated Ocean Drilling Program Management International, Inc.). doi:10.2204/iodp.proc.333.105.2012

Expedition 333 Scientists, 2012d. Site C0018. In Henry, P., Kanamatsu, T., Moe, K., and the Expedition 333 Scientists, Proc. IODP, 333: Tokyo (Integrated Ocean Drilling Program Management International, Inc.). doi:10.2204/iodp.proc.333.103.2012

Gamage, K., Screaton, E., Bekins, B., and Aiello, I., 2011. Permeability-porosity relationships of subduction zone sediments. Mar. Geol., 279(1-4):19-36. doi:10.1016/ j.margeo.2010.10.010

Heki, K., 2007. Secular, transient, and seasonal crustal movements in Japan from a dense GPS array: implication for plate dynamics in convergent boundaries. In Dixon, T.H., and Moore, J.C. (Eds.), The Seismogenic Zone of Subduction Thrust Faults: New York (Columbia Univ. Press), 512-539.

Henry, P., Kanamatsu, T., and Moe, K.T., 2010. NanTroSEIZE Stage 2: subduction inputs 2 and heat flow. IODP Sci. Prosp., 333. doi:10.2204/iodp.sp.333.2010

La Rochelle, P., Sarrailh, J., Tavenas, F., Roy, M., and Leroueil, S., 1981. Causes of sampling disturbance and design of a new sampler for sensitive soils. Can. Geotech. J., 18(1):52-66. doi:10.1139/t81-006

Long, H., Flemings, P.B., Germaine, J.T., and Saffer, D.M., 2011. Consolidation and overpressure near the seafloor in the Ursa Basin, deepwater Gulf of Mexico. Earth Planet. Sci. Lett., 305(1-2):11-20. doi:10.1016/ j.eps1.2011.02.007

Long, H., Flemings, P.B., Germaine, J.T., Saffer, D.M., and Dugan, B., 2008. Data report: consolidation characteristics of sediments from IODP Expedition 308, Ursa Basin, Gulf of Mexico. In Flemings, P.B., Behrmann, J.H., John, C.M., and the Expedition 308 Scientists, Proc. IODP, 308: College Station, TX (Integrated Ocean Drilling Program Management International, Inc.). doi:10.2204/ iodp.proc.308.204.2008
Morgan, J.K., Sunderland, E.B., and Ask, M.V.S., 2007. Deformation and mechanical strength of sediments at the Nankai subduction zone: implications for prism evolution and décollement initiation and propagation. In Dixon, T.H., and Moore, J.C. (Eds.), The Seismogenic Zone of Subduction Thrust Faults: New York (Columbia Univ. Press), 210-256. http://pure.ltu.se/portal/files/ 158069/artikel.pdf

Neuzil, C.E., 1994. How permeable are clays and shales? Water Resour. Res., 30(2):145-150. doi:10.1029/ 93WR02930

Saffer, D.M., 2003. Pore pressure development and progressive dewatering in underthrust sediments at the Costa Rican subduction margin: comparison with northern Barbados and Nankai. J. Geophys. Res.: Solid Earth, 108(B5):2261-2276. doi:10.1029/2002JB001787

Santagata, M.C., and Germaine, J.T., 2002. Sampling disturbance effects in normally consolidated clays. J. Geotech. Geoenviron. Eng., 128(12):997-1006. doi:10.1061/ (ASCE)1090-0241(2002)128:12(997)

Santamarina, J.C., Klein, K.A., Wang, Y.H., and Prencke, E., 2002. Specific surface: determination and relevance. Can. Geotech. J., 39(1):233-241. doi:10.1139/t01-077

Seno, T., Stein, S., and Gripp, A.E., 1993. A model for the motion of the Philippine Sea plate consistent with NUVEL-1 and geological data. J. Geophys. Res.: Solid Earth, 98(B10):17941-17948. doi:10.1029/93JB00782

Tobin, H.J., and Kinoshita, M., 2006. NanTroSEIZE: the IODP Nankai Trough Seismogenic Zone Experiment. Sci. Drill., 2:23-27. doi:10.2204/iodp.sd.2.06.2006

Underwood, M.B., and Guo, J., 2013. Data report: clay mineral assemblages in the Shikoku Basin, NanTroSEIZE subduction inputs, IODP Sites C0011 and C0012. In Saito, S., Underwood, M.B., Kubo, Y., and the Expedition 322 Scientists, Proc. IODP, 322: Tokyo (Integrated Ocean Drilling Program Management International, Inc.). doi:10.2204/iodp.proc.322.202.2013

Initial receipt: 21 Feb 2013

Acceptance: 12 Feb 2014

Publication: 29 April 2014

MS 333-201 
Figure F1. Location map for Sites C0011, C0012, and C0018 (red dots). White dots = NanTroSEIZE Stage 1 and 2 drill sites, white barbed line $=$ position of deformation front of accretionary prism, yellow arrow $=$ estimated far-field vectors between the Philippine Sea plate and Japan (Seno et al., 1993; Heki, 2007).

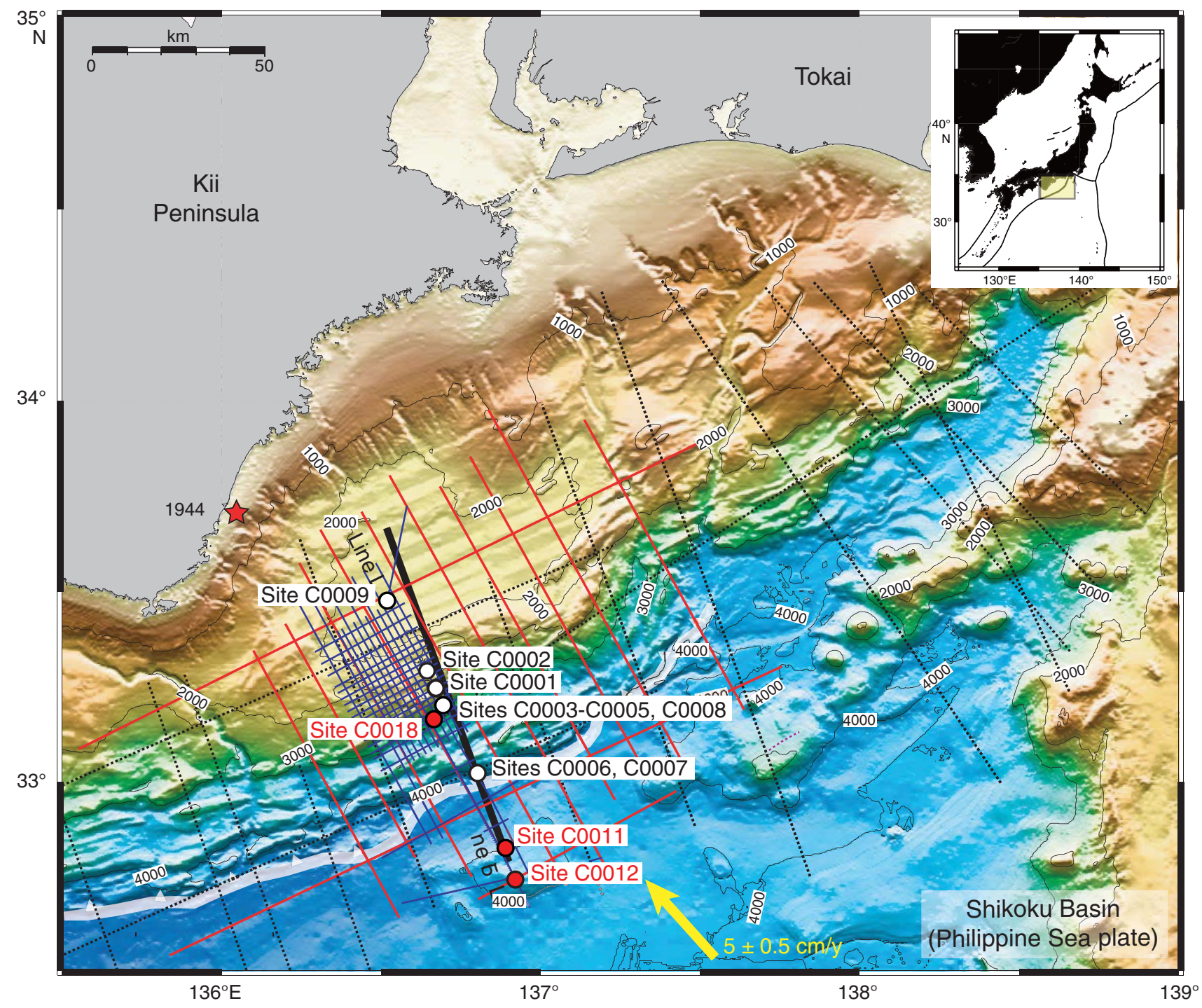


Figure F2. Constant-rate-of-strain (CRS) consolidation experiment data from Experiment CRS100 (Table T2). Blue circles = experiment data. Black line is the fit to the virgin consolidation portion of the data and used to determine $C_{\mathrm{c}}$. Complete data for all CRS consolidation experiments are available in 333_CONSOL in "Supplementary material."

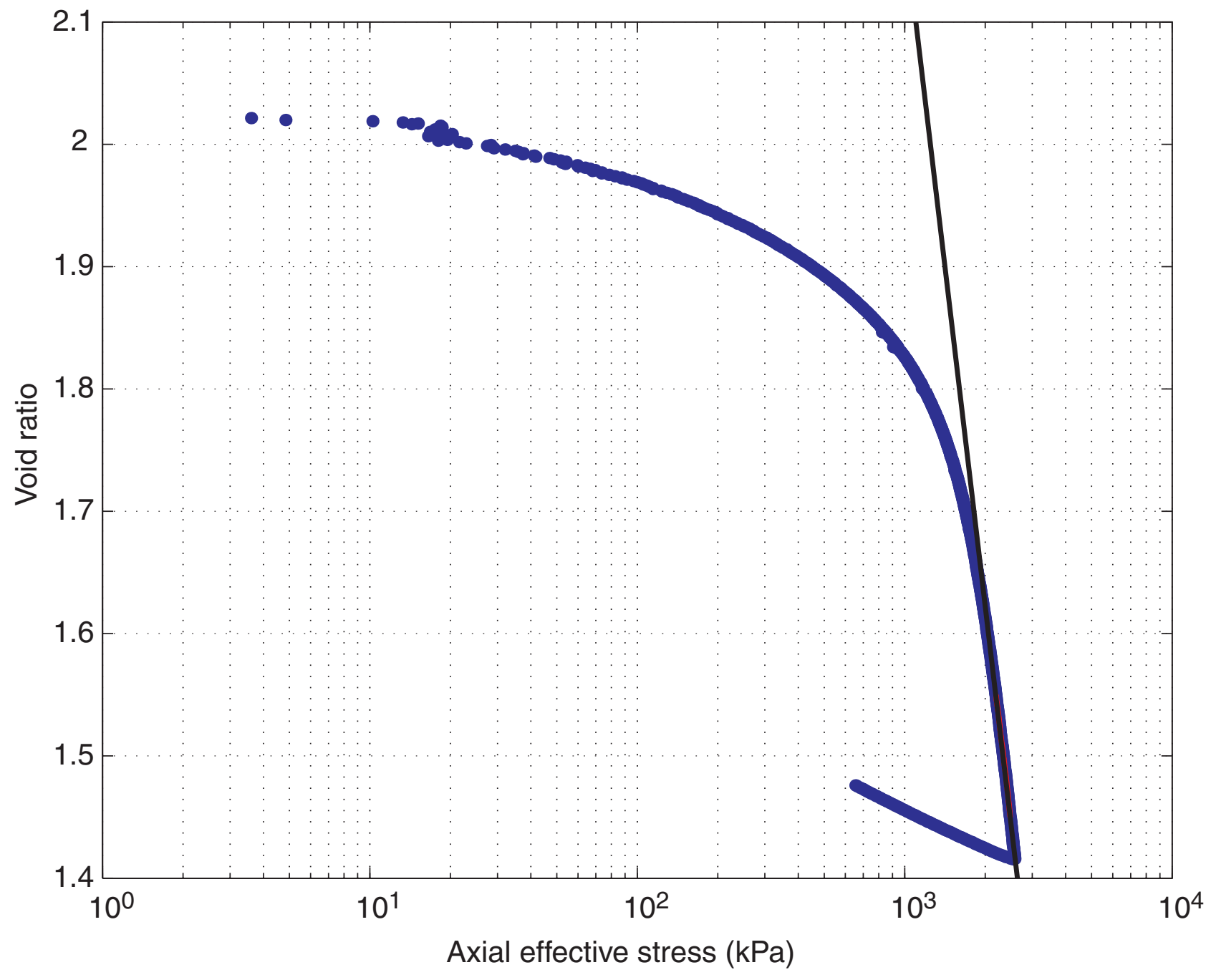


Figure F3. Permeability-porosity data from the virgin consolidation portion of Experiment CRS100 (Table T2). Blue circles $=$ experiment data. Black line is the fit to the data used to determine $k_{0}$ at the initial porosity (white circle).

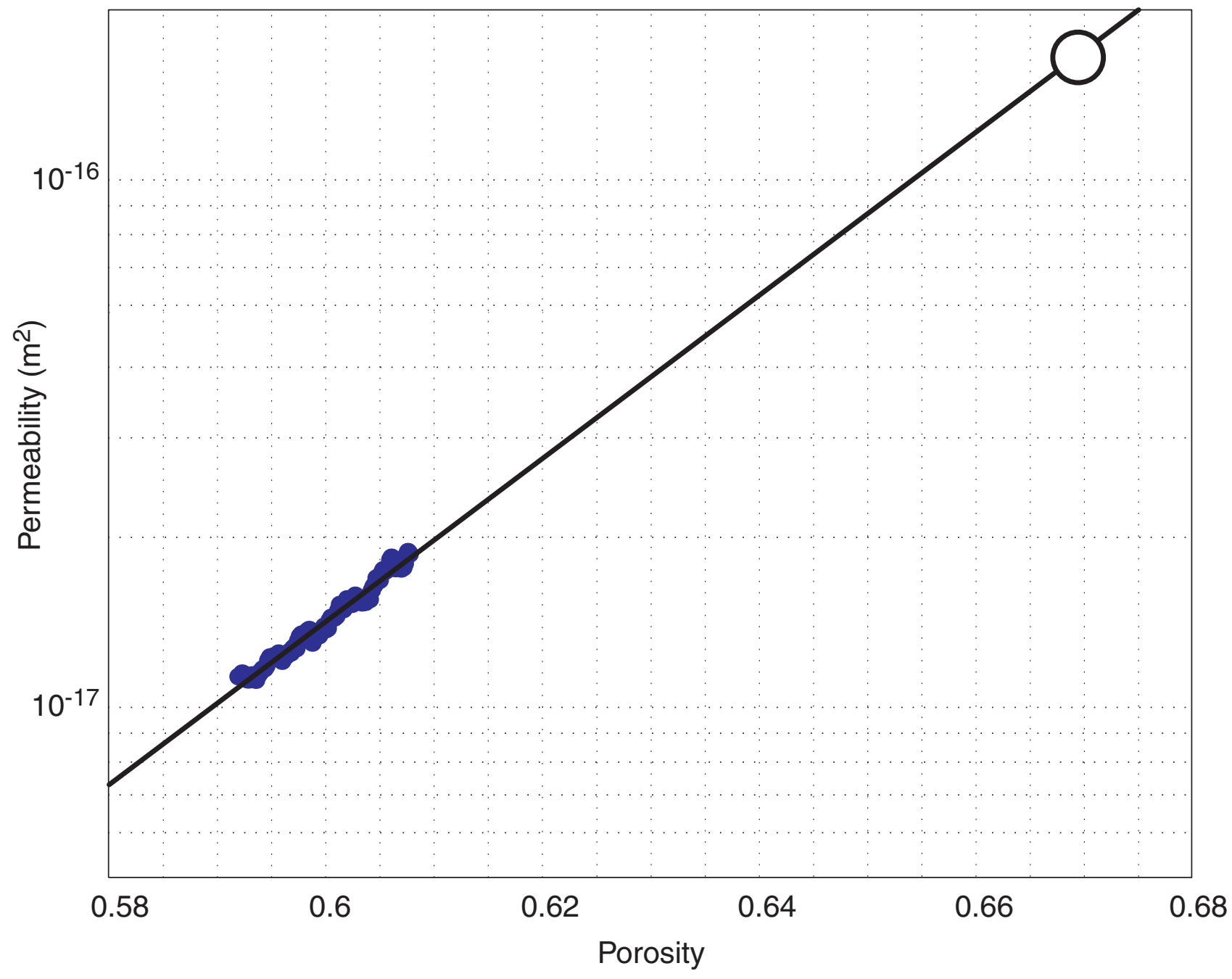


Figure F4. Work-stress data from Experiment CRS100 (Table T2). Blue circles = experiment data. Blue and red circles correspond respectively to the preyield and virgin consolidation (postyield) portions of the data used to constrain $\sigma_{p c}{ }^{\prime}$. Black lines are the fit to these portions of the data. Intersection of lines corresponds to $\sigma_{p c}{ }^{\prime}$ (white circle).

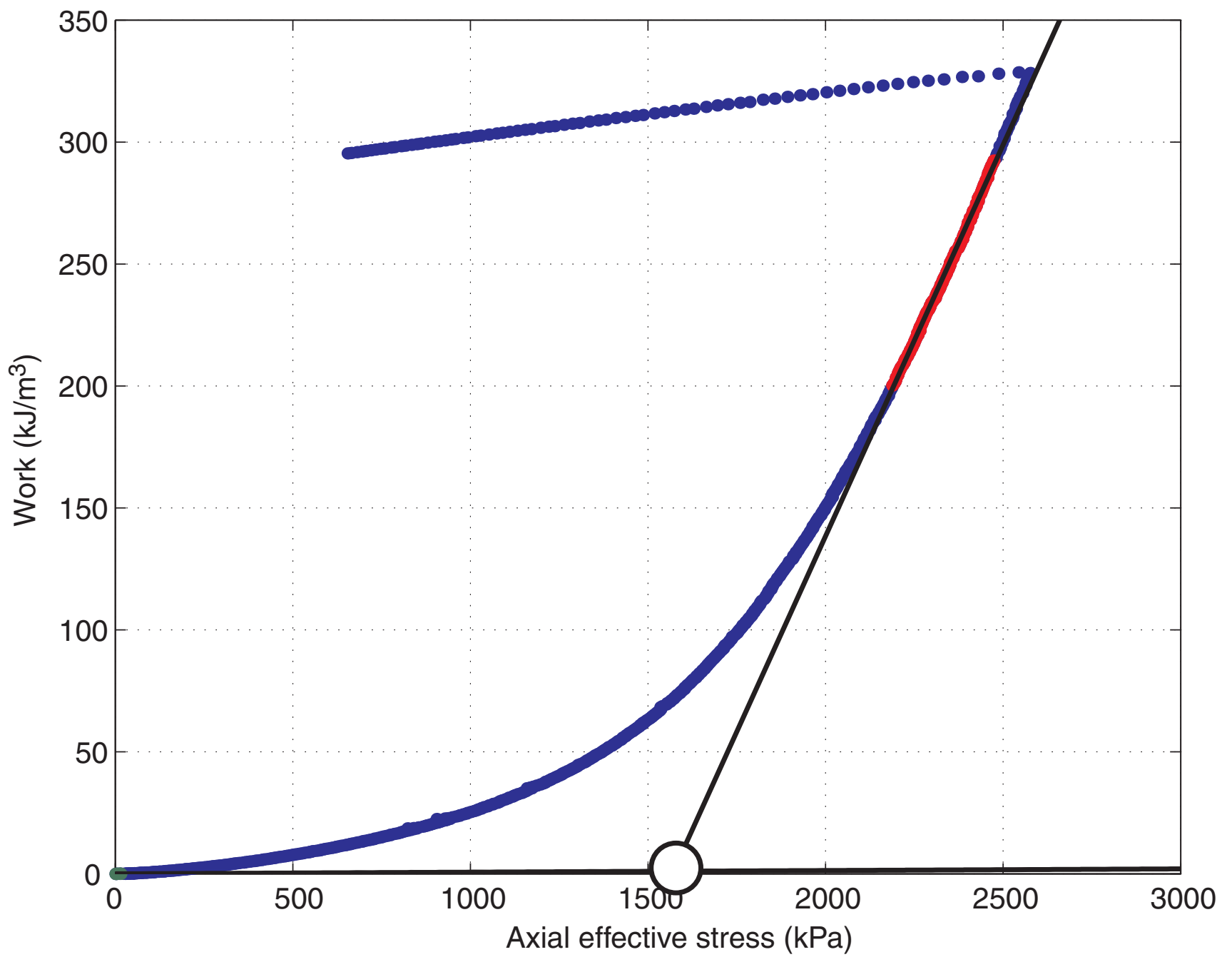


Figure F5. Porosity for all samples. Red squares = laboratory data, black dots = shipboard moisture and density (MAD) measurements.

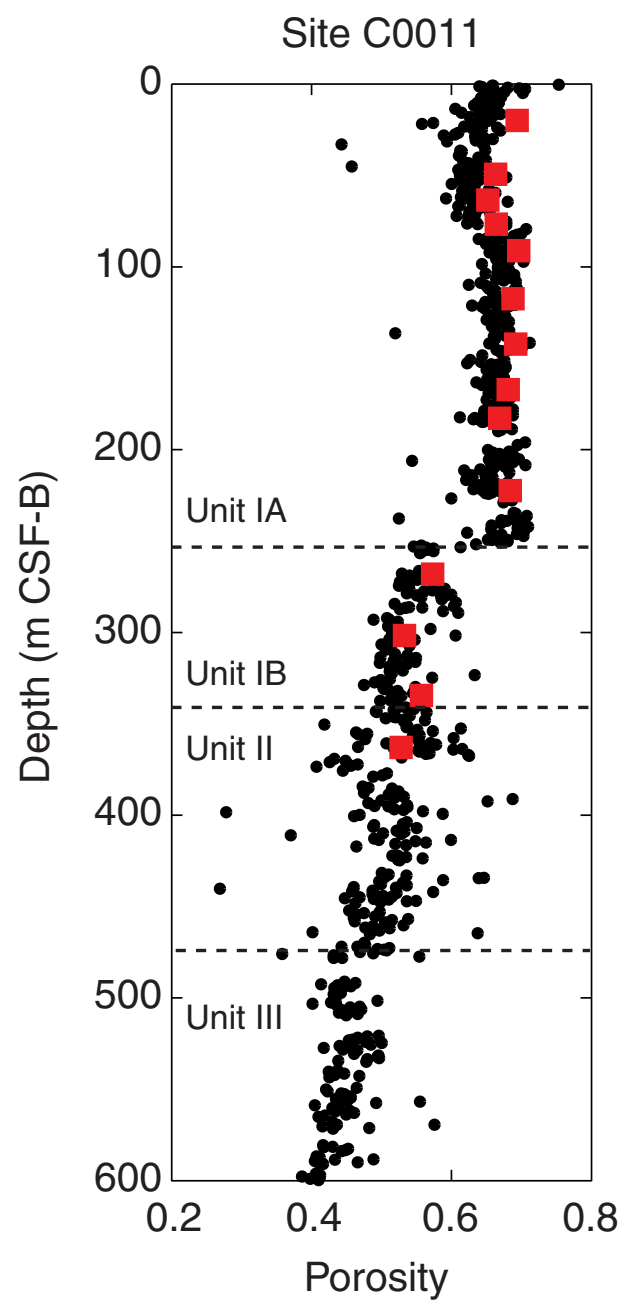

Site $\mathrm{C} 0012$

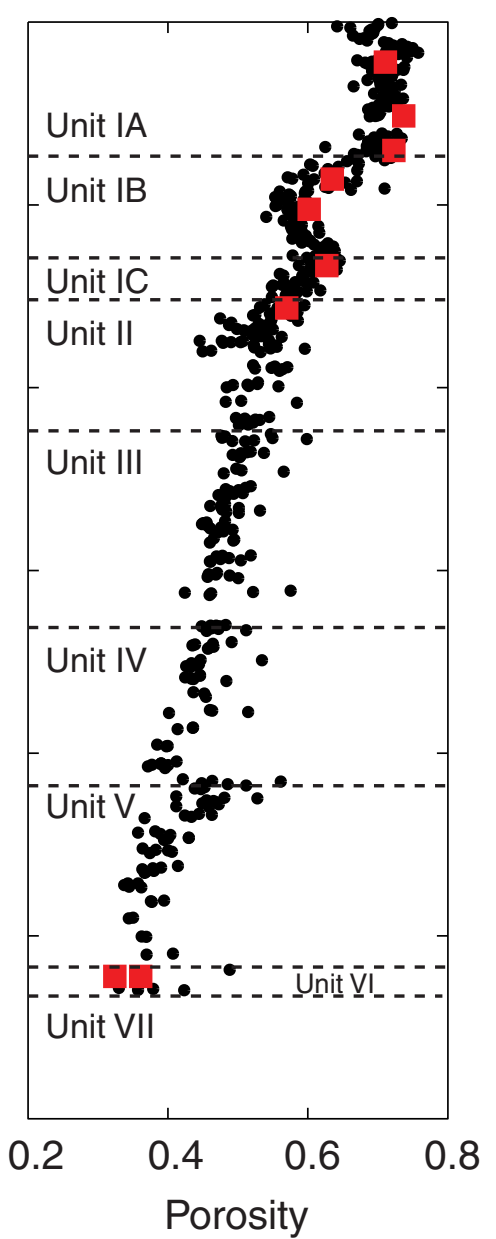

- Shipboard MAD

- Laboratory
Site C0018

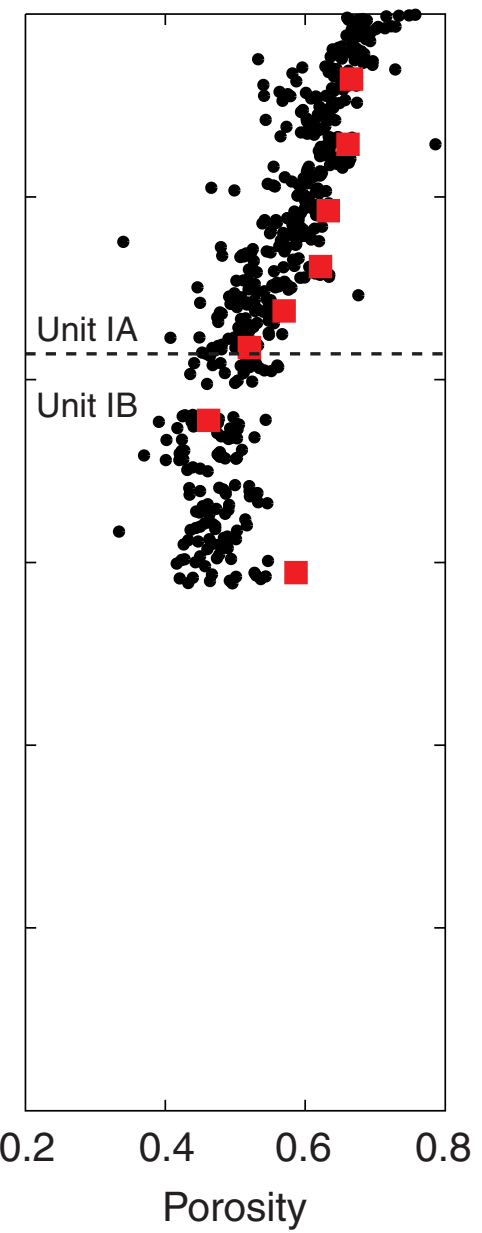


Figure F6. Results of CRS consolidation, methylene blue, and grain size measurements, Site C0011. A. Permeability at initial porosity $\left(k_{0}\right)$. B. Compression index $\left(C_{\mathrm{c}}\right)$. C. Overconsolidation ratio. D. Specific surface $\left(S_{\mathrm{a}}\right)$. E. Median grain diameter $\left(D_{50}\right)$. F. Sand, silt, and clay mass fractions.

A

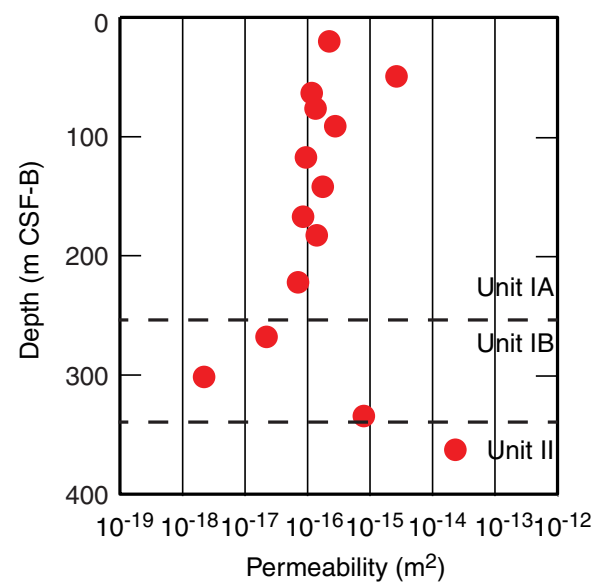

D

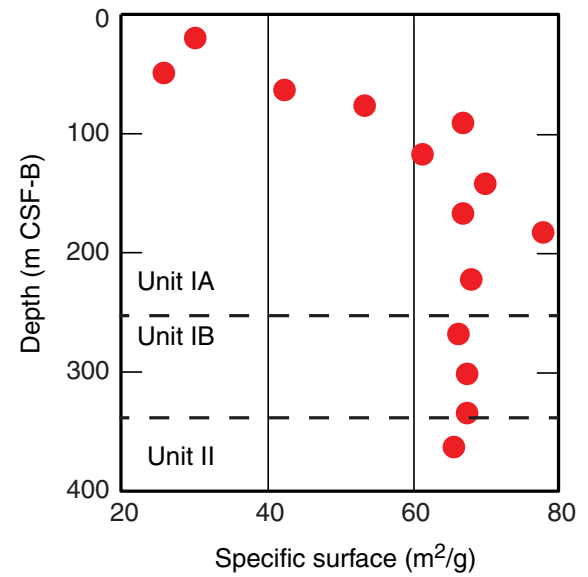

B

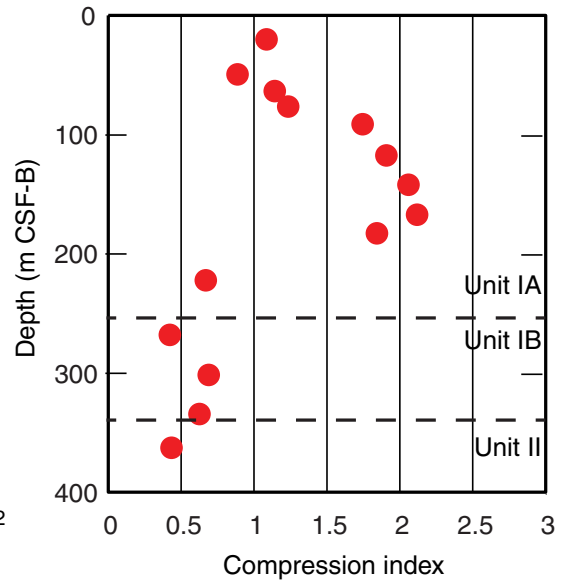

$\mathbf{E}$

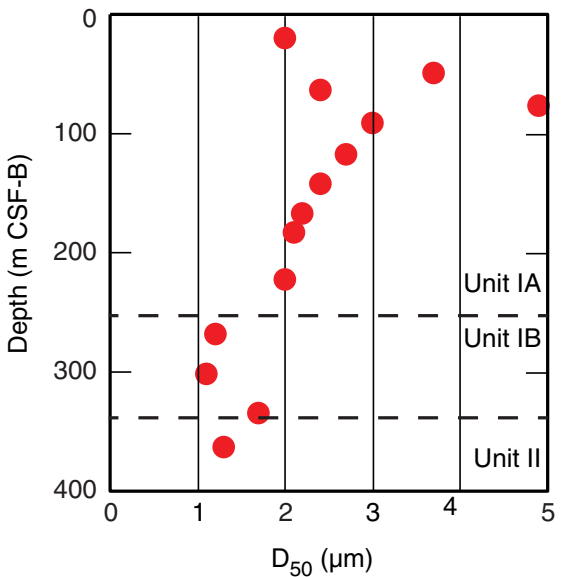

C

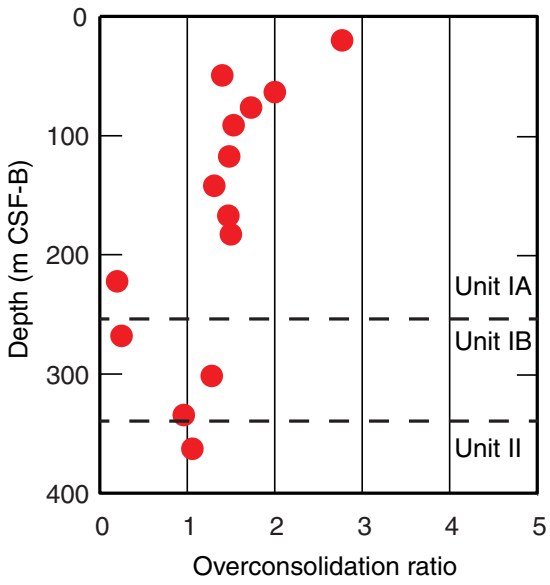

F

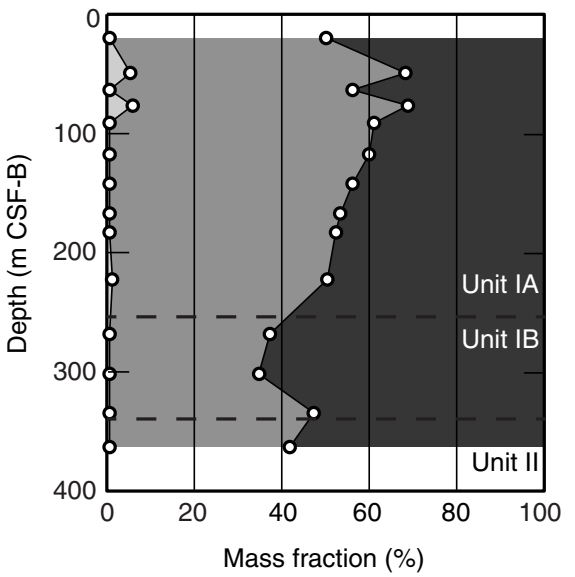

Sand

Silt

Clay 
Figure F7. Results of CRS consolidation, methylene blue, and grain size measurements, Site C0012. A. Permeability at initial porosity $\left(k_{0}\right)$. B. Compression index $\left(C_{c}\right)$. C. Overconsolidation ratio. D. Specific surface $\left(S_{\mathrm{a}}\right)$. E. Median grain diameter $\left(D_{50}\right)$. F. Sand, silt, and clay mass fractions.

A

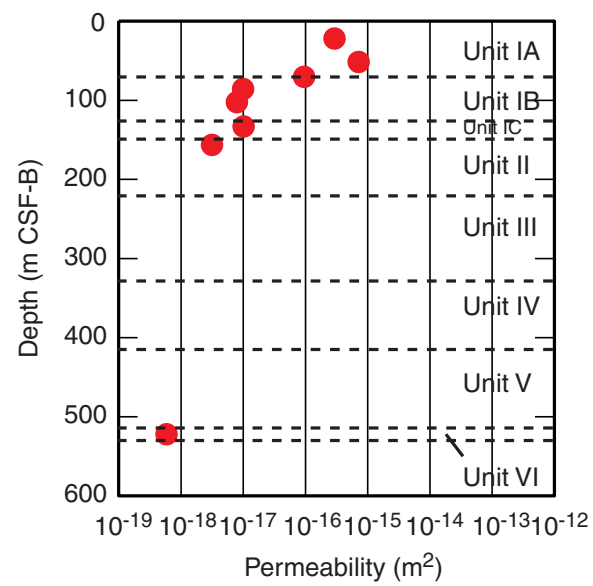

D

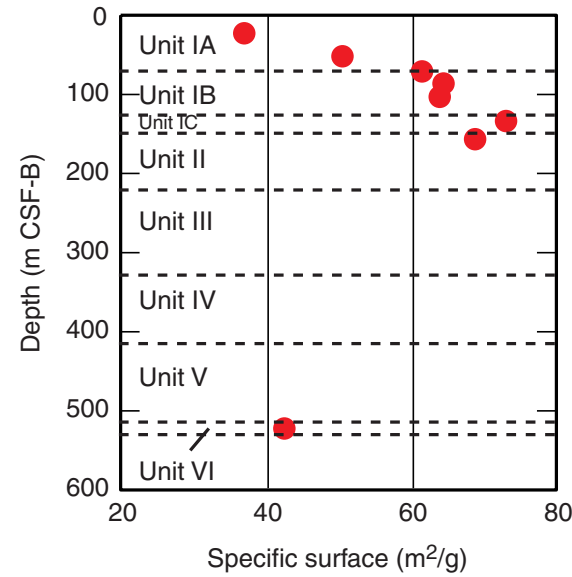

B

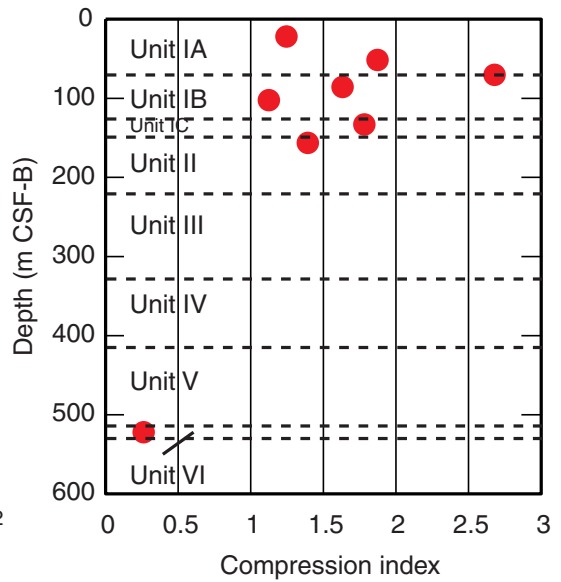

E

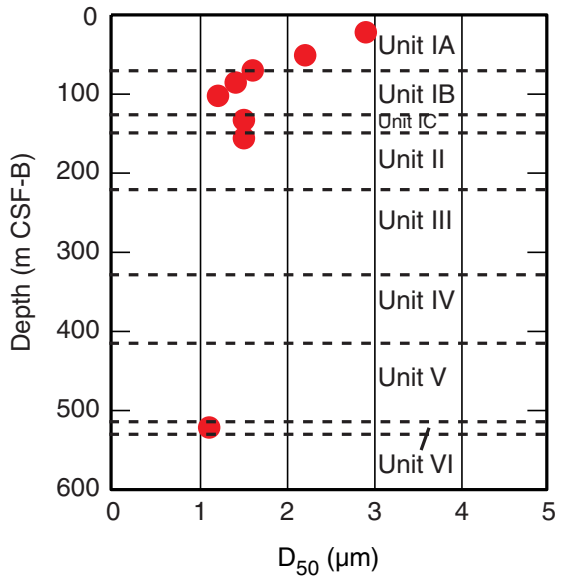

C

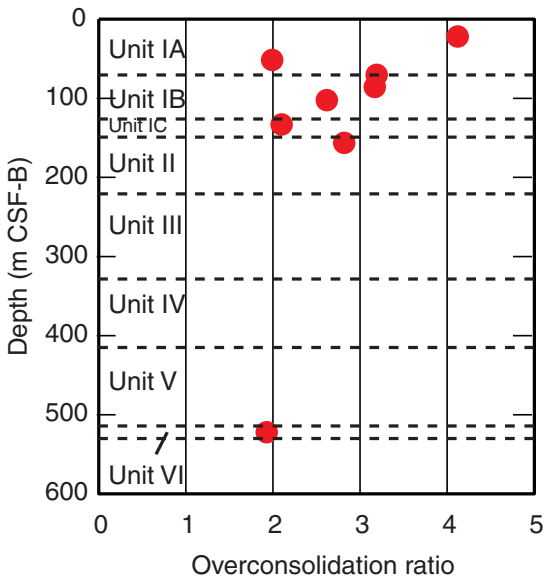

F

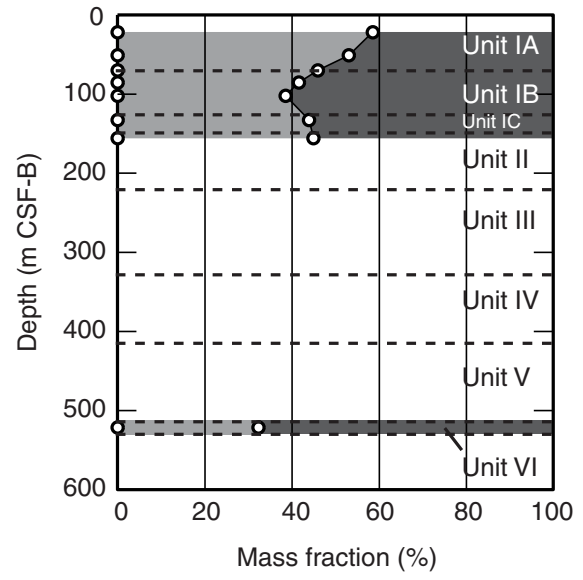

Sand

Silt

Clay 
Figure F8. Results of CRS consolidation, methylene blue, and grain size measurements, Site C0018. Tan shaded area $=$ depth interval of Mass Transport Deposit 6 . A. Permeability at initial porosity $\left(k_{0}\right)$. B. Compression index $\left(C_{c}\right)$. C. Overconsolidation ratio. D. Specific surface $\left(S_{\mathrm{a}}\right)$. E. Median grain diameter $\left(D_{50}\right)$. F. Sand, silt, and clay mass fractions.

A

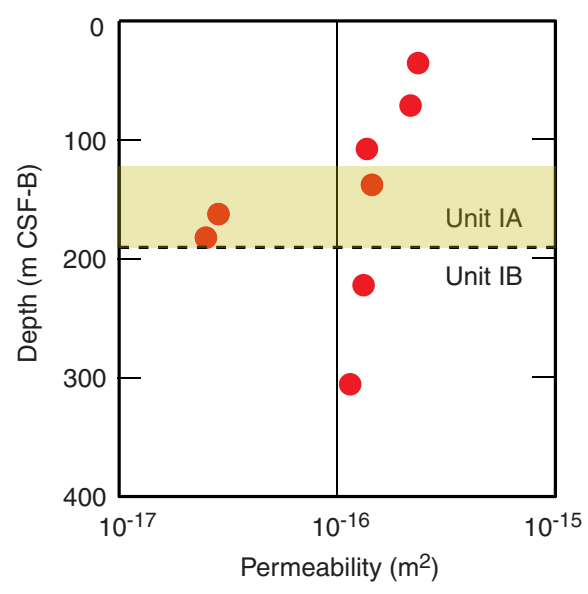

D

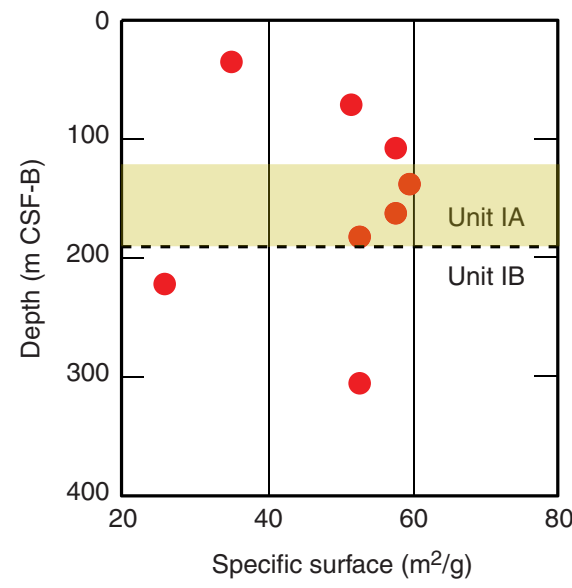

B

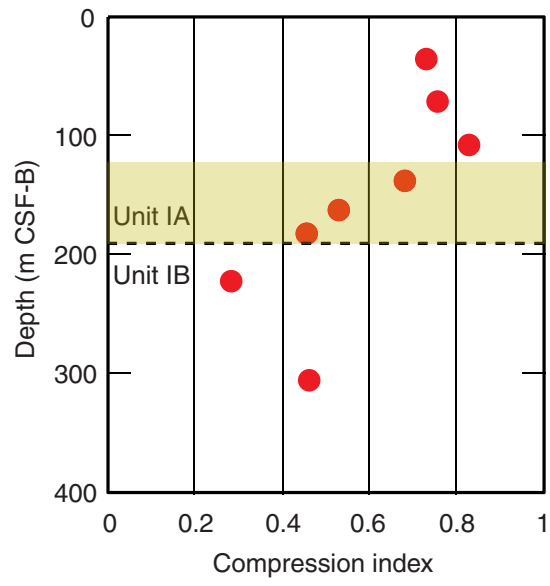

E

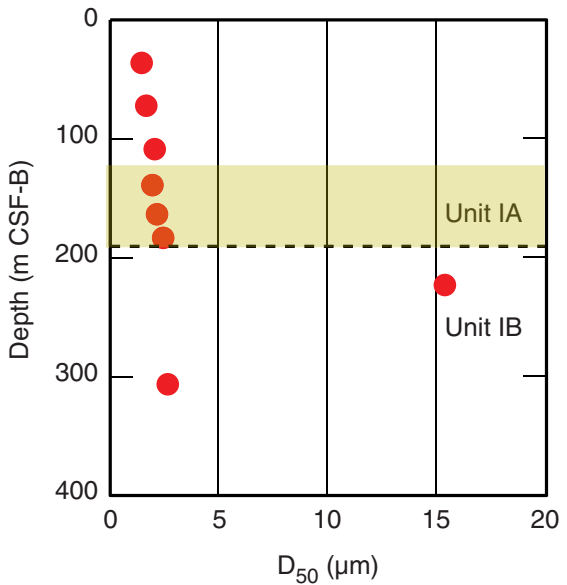

C

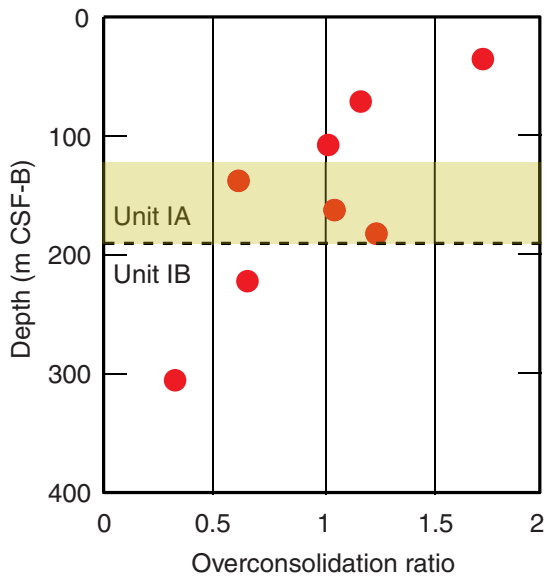

$\mathbf{F}$

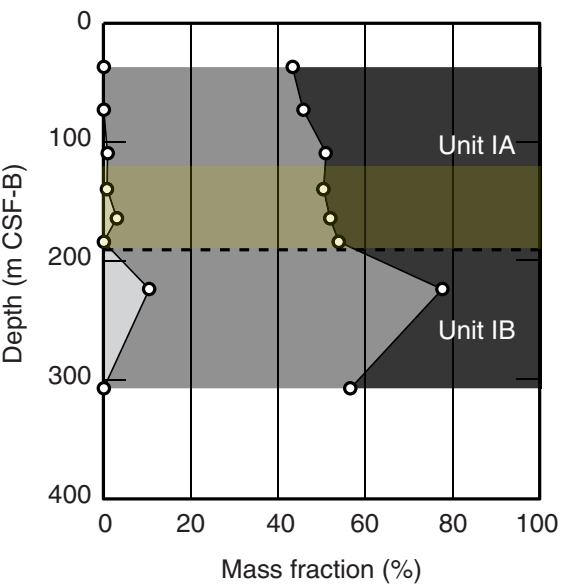

Sand

Silt

Clay 
Figure F9. Comparison of specific surface $\left(S_{\mathrm{a}}\right)$ and median grain diameter $\left(D_{50}\right)$ values for all sites.

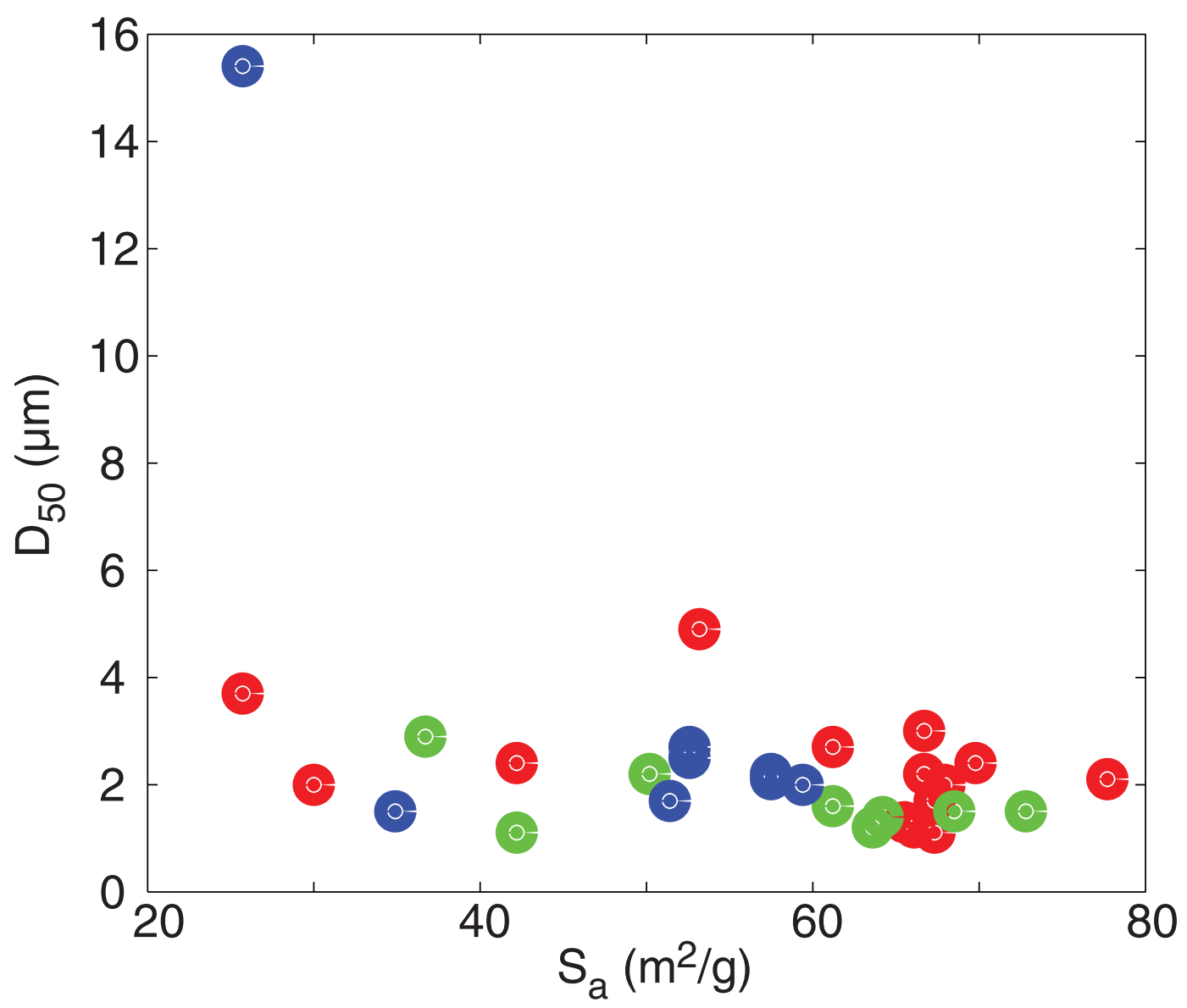

$\mathrm{C} 0011$ $\mathrm{C} 0012$ $\mathrm{C} 0018$ 
Figure F10. Results of mercury injection capillary pressure measurements, Site C0011. A. Median pore radius $\left(r_{50}\right)$. B. Air-water capillary entry pressure $\left(P_{c}\right)$. C. Median pore radius $\left(r_{50}\right)$ vs. permeability at reference void ratio $\left(k_{0}\right)$. D. Air-water capillary entry pressure $\left(P_{\mathrm{c}}\right)$ vs. permeability at initial porosity $\left(k_{0}\right)$.

A
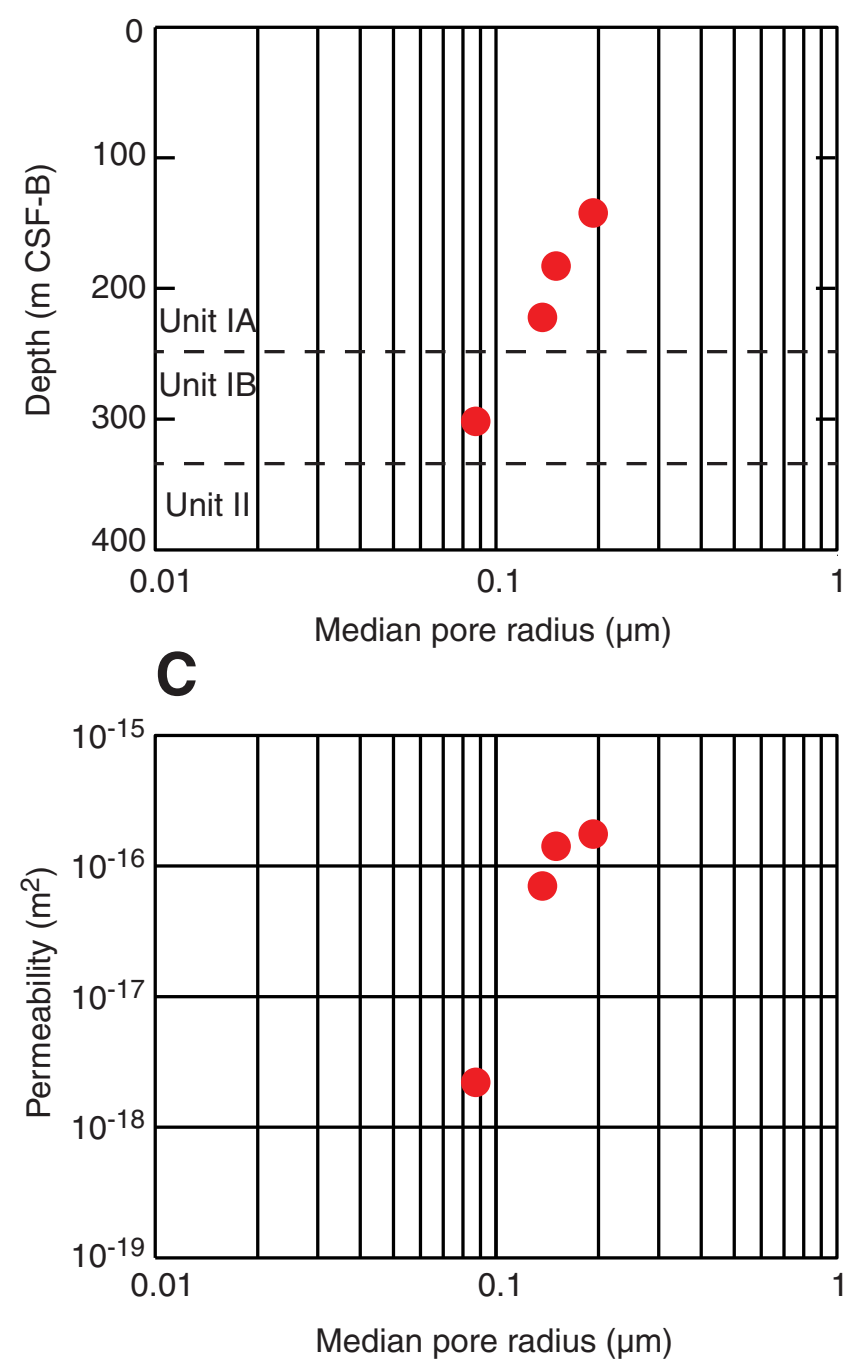

B
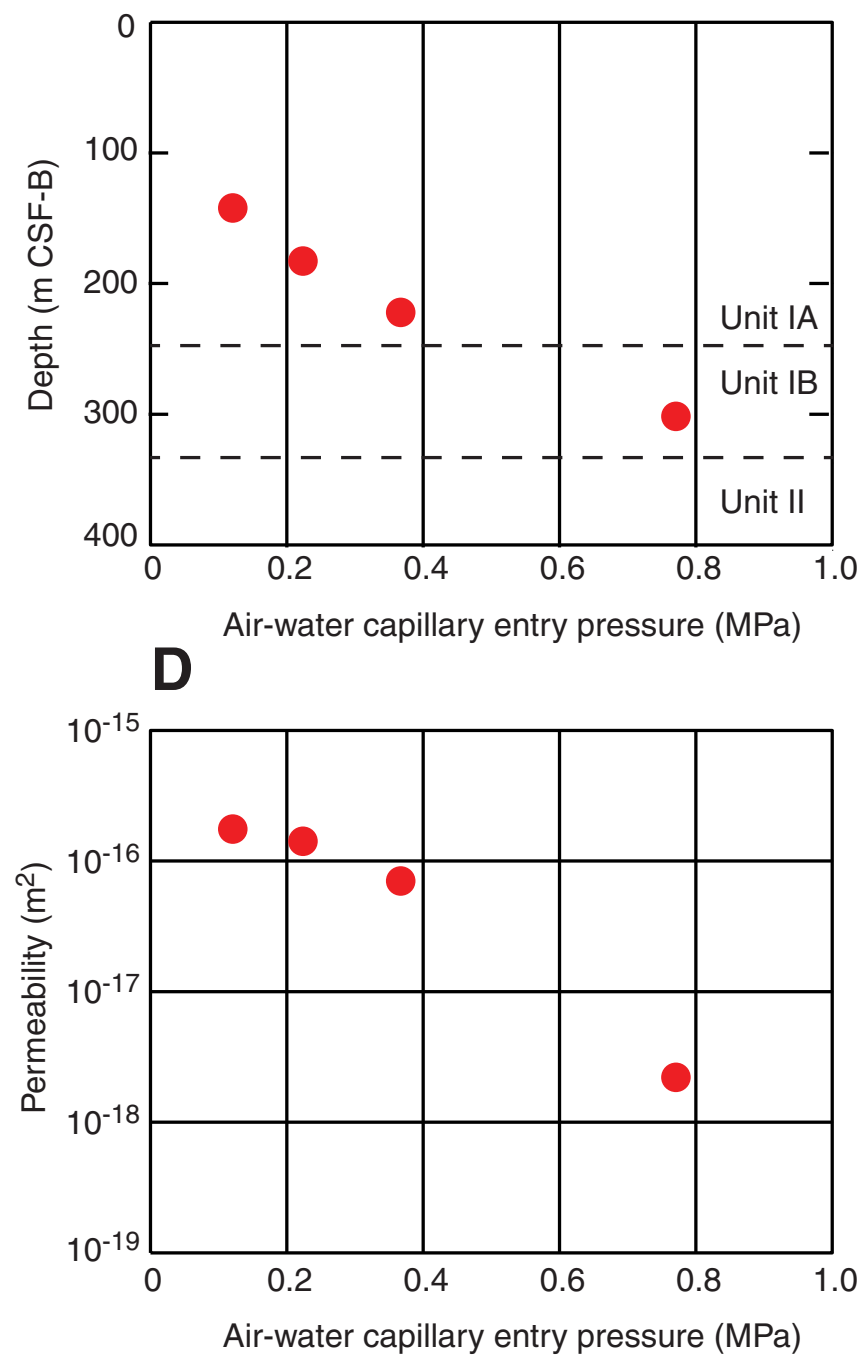
Figure F11. Results of mercury injection capillary pressure measurements, Site C0012. A. Median pore radius $\left(r_{50}\right)$. B. Air-water capillary entry pressure $\left(P_{c}\right)$. C. Median pore radius $\left(r_{50}\right)$ vs. permeability at reference void ratio $\left(k_{0}\right)$. D. Air-water capillary entry pressure $\left(P_{\mathrm{c}}\right)$ vs. permeability at initial porosity $\left(k_{0}\right)$.

A
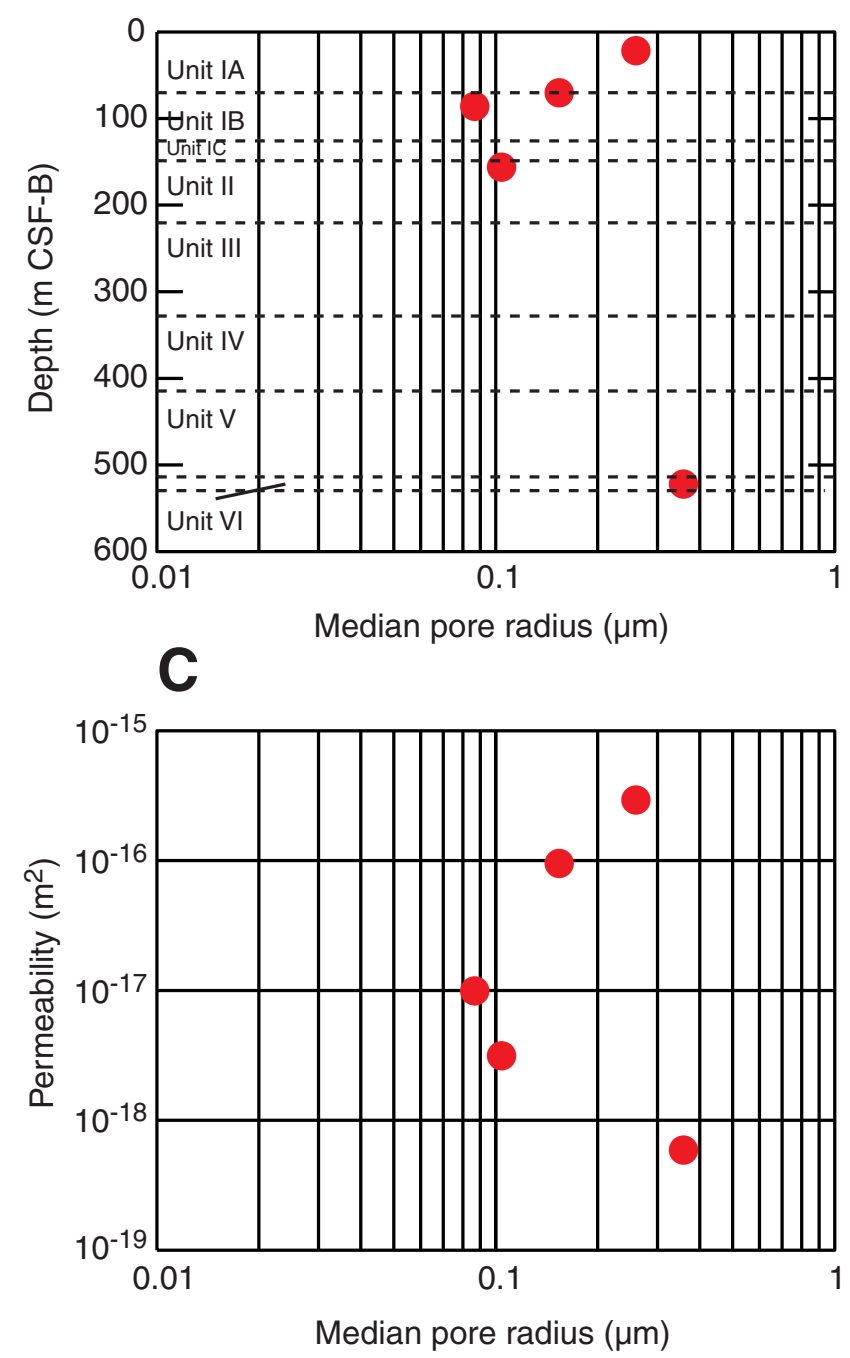

B
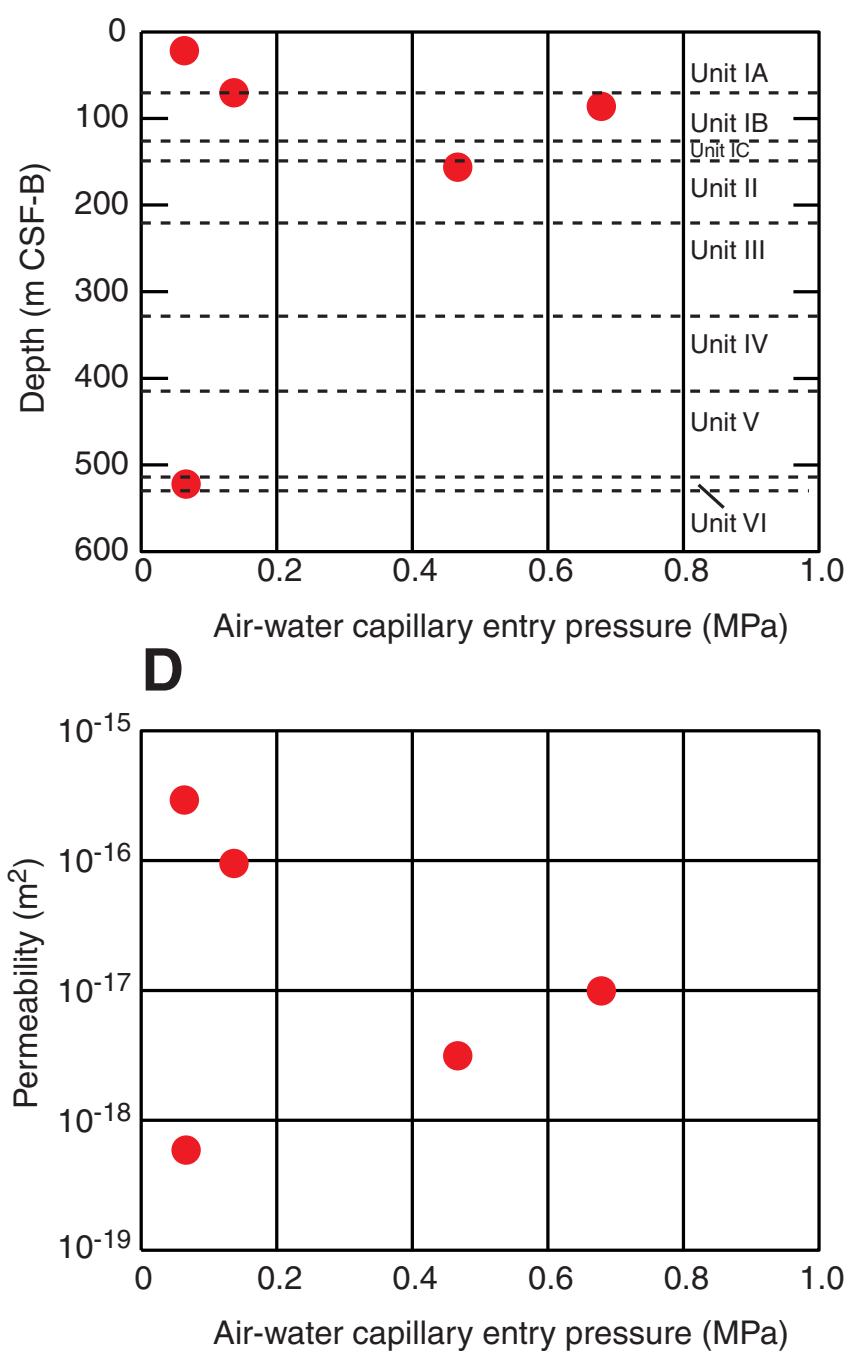
Figure F12. Results of mercury injection capillary pressure measurements, Site C0018. Tan shaded area $=$ depth interval of Mass Transport Deposit 6. A. Median pore radius $\left(r_{50}\right)$. B. Air-water capillary entry pressure $\left(P_{\mathrm{c}}\right)$. C. Median pore radius $\left(r_{50}\right)$ vs. permeability at reference void ratio $\left(k_{0}\right)$. D. Air-water capillary entry pressure $\left(P_{\mathrm{c}}\right)$ vs. permeability at initial porosity $\left(k_{0}\right)$.

A
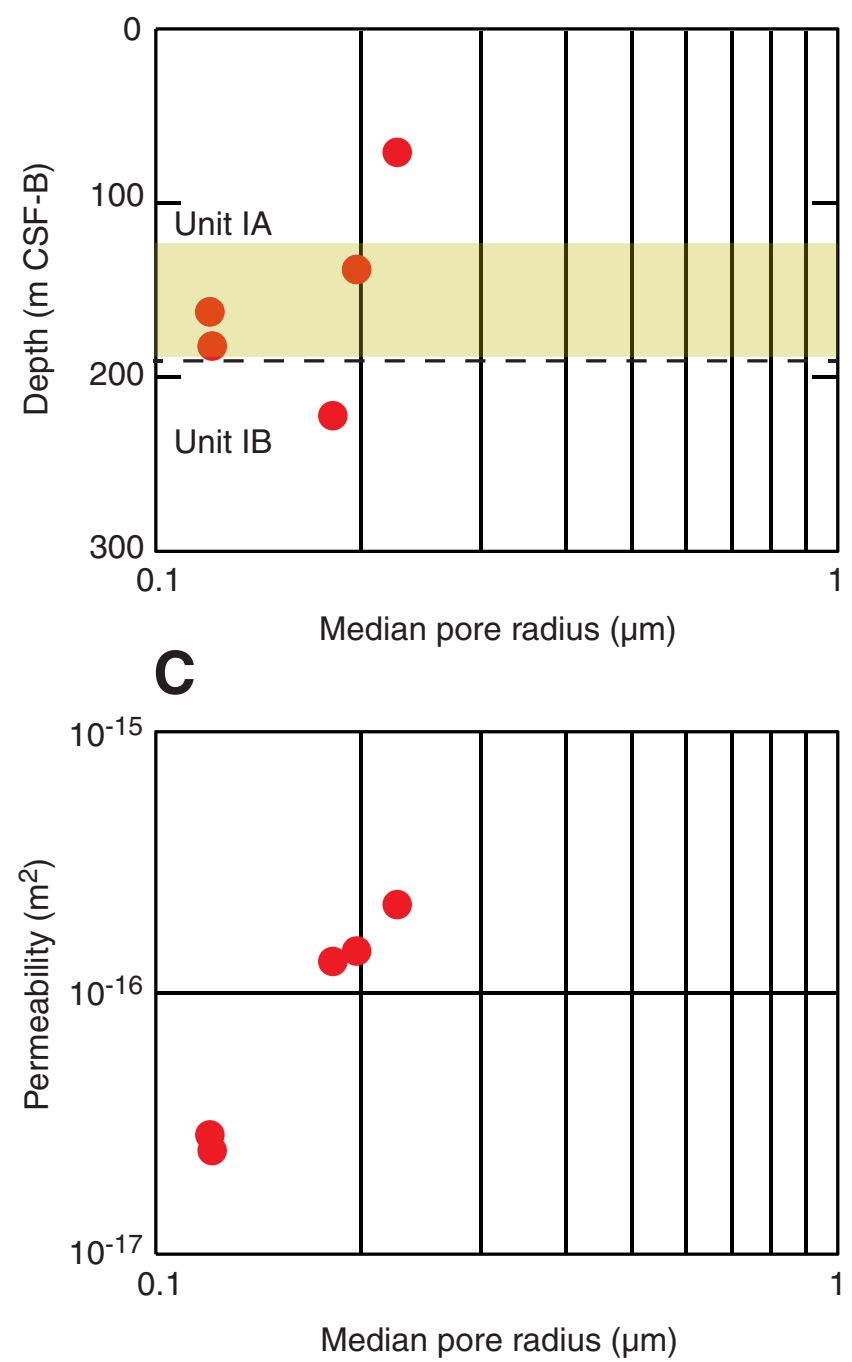

B
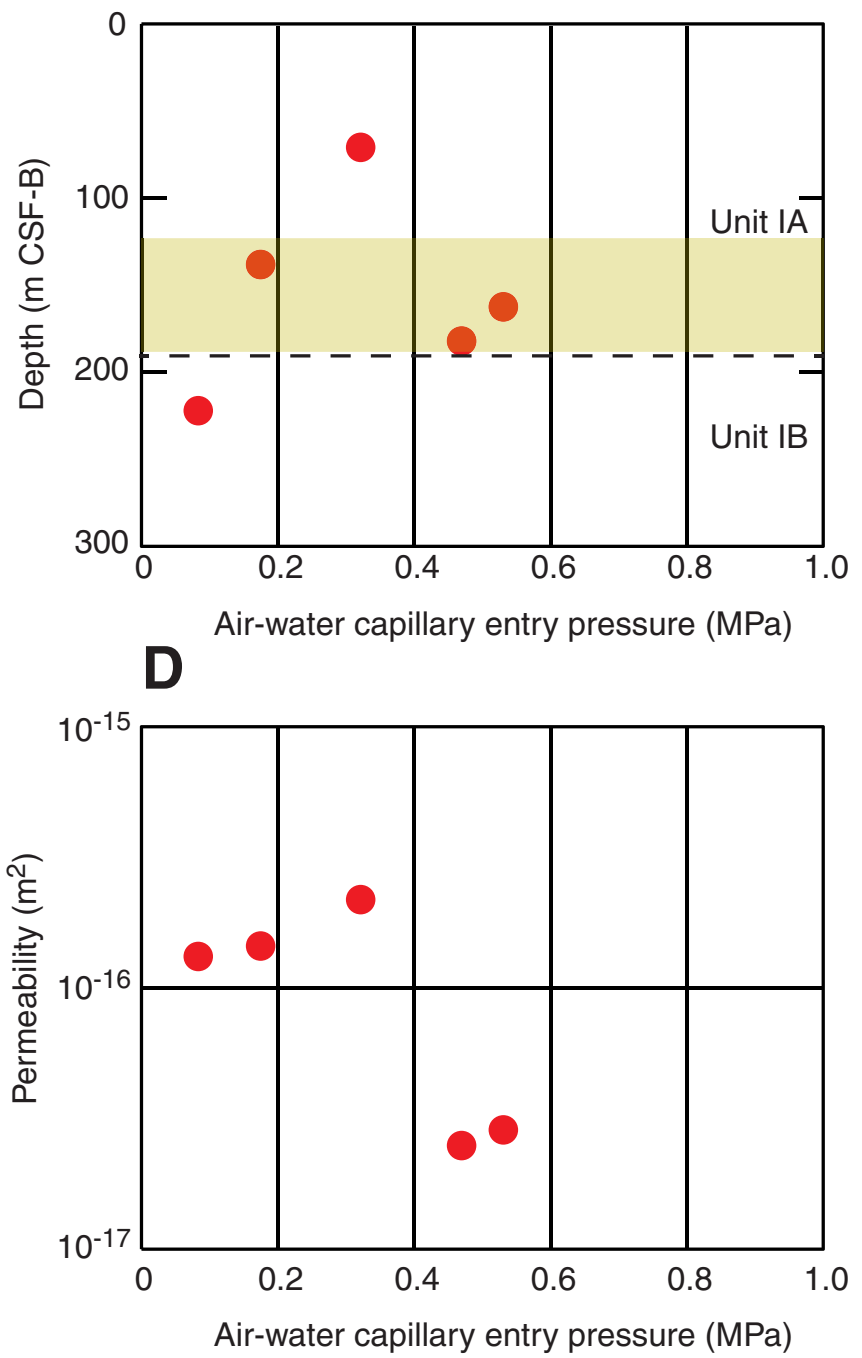
Table T1. Nomenclature.

\begin{tabular}{|c|c|c|c|}
\hline Variable & Definition & Dimension & Unit \\
\hline$A_{\mathrm{MB}}$ & Mineral surface area covered by one molecule of methylene blue & $L^{2}$ & $\mathrm{~m}^{2}$ \\
\hline$A_{v}$ & Avogadro's number & Dimensionless & - \\
\hline$C_{c}$ & Compression index & Dimensionless & - \\
\hline$c_{\mathrm{v}}$ & Coefficient of consolidation & $\mathrm{L}^{2} / \mathrm{T}$ & $\mathrm{m}^{2} / \mathrm{s}$ \\
\hline$D$ & Particle diameter & L & $\mathrm{m}$ \\
\hline$D_{25}$ & Particle diameter at which $25 \%$ are smaller by mass & $\mathrm{L}$ & $\mu \mathrm{m}$ \\
\hline$D_{50}$ & Median particle diameter & $\mathrm{L}$ & $\mu \mathrm{m}$ \\
\hline$D_{75}$ & Particle diameter at which $75 \%$ are smaller by mass & $\mathrm{L}$ & $\mu \mathrm{m}$ \\
\hline e & Void ratio & Dimensionless & - \\
\hline$e_{0}$ & Reference void ratio & Dimensionless & - \\
\hline$e_{\sigma a^{\prime}}$ & Void ratio at axial effective stress & Dimensionless & - \\
\hline g & Acceleration due to gravity & $\mathrm{L} / \mathrm{T}^{2}$ & $\mathrm{~m} / \mathrm{s}^{2}$ \\
\hline$H$ & Instantaneous sample height & L & $\mathrm{m}$ \\
\hline$H_{0}$ & Initial sample height & $\mathrm{L}$ & $\mathrm{m}$ \\
\hline$k$ & Permeability & $\mathrm{L}^{2}$ & $\mathrm{~m}^{2}$ \\
\hline$k_{0}$ & Permeability at reference void ratio & $\mathrm{L}^{2}$ & $\mathrm{~m}^{2}$ \\
\hline$L$ & Effective depth from solution surface to center of hydrometer bulb & $\mathrm{L}$ & $\mathrm{m}$ \\
\hline$M_{\mathrm{m}}$ & Molar mass of methylene blue & M & $\mathrm{g} / \mathrm{mol}$ \\
\hline$m_{\mathrm{p}}$ & Mass fraction of particles remaining in suspension & Dimensionless & - \\
\hline$m_{\mathrm{s}}$ & Dry mass of specimen & M & $\mathrm{kg}$ \\
\hline$m_{\mathrm{v}}$ & Coefficient of volume compressibility & $\mathrm{LT}^{2} / \mathrm{M}$ & $1 / \mathrm{Pa}$ \\
\hline$N$ & Number of methylene blue increments & Dimensionless & - \\
\hline OCR & Overconsolidation ratio & Dimensionless & - \\
\hline$P_{\mathrm{c}}$ & Air-water capillary pressure & $\mathrm{M} / \mathrm{LT}^{2}$ & $\mathrm{~Pa}$ \\
\hline$P_{\mathrm{Hg}}$ & Mercury injection pressure & $\mathrm{M} / \mathrm{LT}^{2}$ & $\mathrm{~Pa}$ \\
\hline$r_{50}$ & Median pore radius & $\mathrm{L}$ & $\mu \mathrm{m}$ \\
\hline$r_{\mathrm{p}}$ & Pore radius & $\mathrm{L}$ & $\mathrm{m}$ \\
\hline$S_{a}$ & Specific surface & $\mathrm{L}^{2} / \mathrm{M}$ & $\mathrm{m}^{2} / \mathrm{g}$ \\
\hline$t$ & Time & $\mathrm{T}$ & s \\
\hline$V$ & Volume of solution & $\mathrm{L}^{3}$ & $\mathrm{~m}^{3}$ \\
\hline$\Delta_{\mathrm{u}}$ & Base excess pressure & $\mathrm{M} / \mathrm{LT}^{2}$ & $\mathrm{~Pa}$ \\
\hline$\Delta W$ & Work per unit volume & $\mathrm{M} / \mathrm{LT}^{2}$ & $\mathrm{~J} / \mathrm{m}^{3}$ \\
\hline$z$ & Depth below seafloor & $\mathrm{L}$ & $\mathrm{m}$ \\
\hline$\varepsilon$ & Axial strain & Dimensionless & - \\
\hline$\varepsilon_{\sigma a^{\prime}}$ & Axial strain at axial effective stress & Dimensionless & - \\
\hline$\dot{\varepsilon}$ & Strain rate & $1 / \mathrm{T}$ & $1 / \mathrm{s}$ \\
\hline$\theta_{\mathrm{aw}}$ & Air-water contact angle & Dimensionless & - \\
\hline$\theta_{\mathrm{Hg}}$ & Mercury-sediment contact angle & Dimensionless & - \\
\hline$\mu$ & Viscosity & $\mathrm{M} / \mathrm{LT}$ & $\mathrm{Pa} \cdot \mathrm{s}$ \\
\hline$\rho$ & Hydrometer reading & $M / L^{3}$ & $\mathrm{~kg} / \mathrm{m}^{3}$ \\
\hline$\rho_{\mathrm{f}}$ & Density of solution without sediment & $M / L^{3}$ & $\mathrm{~kg} / \mathrm{m}^{3}$ \\
\hline$\rho_{\mathrm{s}}$ & Specimen grain density & $M / L^{3}$ & $\mathrm{~kg} / \mathrm{m}^{3}$ \\
\hline$\sigma_{\mathrm{a}}^{\prime}(\mathrm{MPa})$ & Axial effective stress & $\mathrm{M} / \mathrm{LT}^{2}$ & $\mathrm{~Pa}$ \\
\hline$\sigma_{\mathrm{aw}}$ & Air-water interfacial tension & $\mathrm{M} / \mathrm{T}^{2}$ & $\mathrm{~N} / \mathrm{m}$ \\
\hline$\sigma_{\mathrm{Hg}}$ & Air-mercury interfacial tension & $\mathrm{M} / \mathrm{T}^{2}$ & $\mathrm{~N} / \mathrm{m}$ \\
\hline$\sigma_{\mathrm{pc}}^{\prime}(\mathrm{MPa})$ & Maximum vertical effective stress & $\mathrm{M} / \mathrm{LT}^{2}$ & $\mathrm{~Pa}$ \\
\hline$\sigma_{v}{ }^{\prime}(\mathrm{MPa})$ & Vertical effective stress & $\mathrm{M} / \mathrm{LT}^{2}$ & $\mathrm{~Pa}$ \\
\hline$\sigma_{\mathrm{vh}}^{\prime}(\mathrm{MPa})$ & Vertical effective stress under hydrostatic conditions & $\mathrm{M} / \mathrm{LT}^{2}$ & $\mathrm{~Pa}$ \\
\hline$\phi_{0}$ & Reference porosity & Dimensionless & - \\
\hline
\end{tabular}


Table T2. Data from consolidation, grain size, and specific surface measurements.

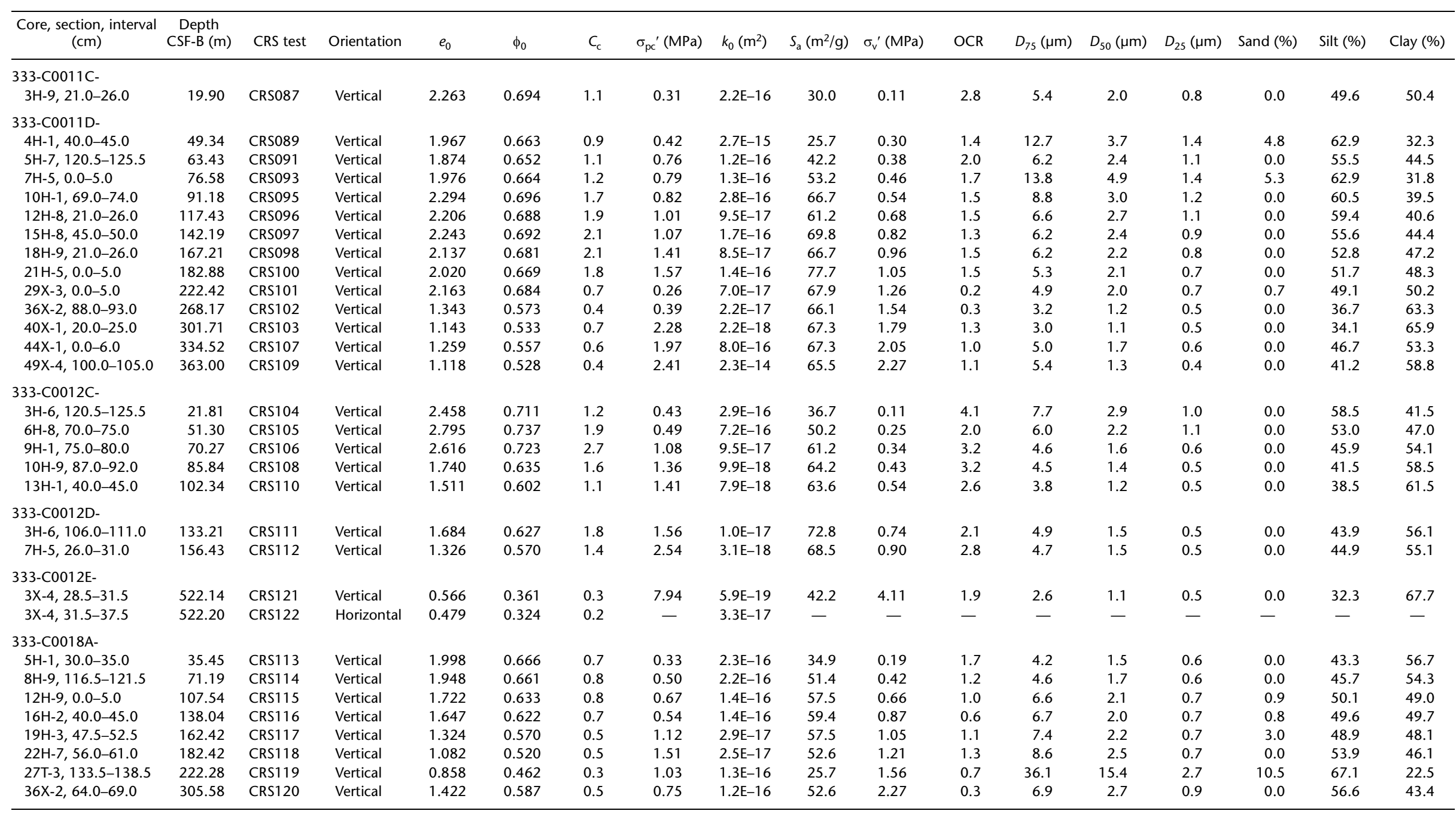

CRS = constant-rate-of-strain. OCR $=$ overconsolidation ratio. All nomenclature is defined in Table T1 1 
Table T3. Data from mercury injection capillary pressure measurements.

\begin{tabular}{|c|c|c|c|c|}
\hline $\begin{array}{l}\text { Core, section, interval } \\
\qquad(\mathrm{cm})\end{array}$ & $\begin{array}{c}\text { Depth } \\
\text { CSF-B (m) }\end{array}$ & $r_{50}(\mu \mathrm{m})$ & $P_{\mathrm{Hg}}(\mathrm{kPa})$ & $P_{c}(\mathrm{kPa})$ \\
\hline \multicolumn{5}{|l|}{ 333-C0011D- } \\
\hline $15 \mathrm{H}-8,45.0-50.0$ & 142.19 & 0.193 & 627 & 121 \\
\hline $21 \mathrm{H}-5,0.0-5.0$ & 182.88 & 0.150 & 1158 & 224 \\
\hline $29 X-3,0.0-5.0$ & 222.42 & 0.137 & 1896 & 367 \\
\hline $40 X-1,20.0-25.0$ & 301.71 & 0.087 & 3985 & 771 \\
\hline \multicolumn{5}{|l|}{ 333-C0012C- } \\
\hline $3 \mathrm{H}-6,120.5-125.5$ & 21.81 & 0.259 & 329 & 64 \\
\hline $9 \mathrm{H}-1,75.0-80.0$ & 70.27 & 0.154 & 710 & 137 \\
\hline $10 \mathrm{H}-9,87.0-92.0$ & 85.84 & 0.087 & 3509 & 679 \\
\hline \multicolumn{5}{|l|}{ 333-C0012D- } \\
\hline 7H-5, 26.0-31.0 & 156.43 & 0.104 & 2413 & 467 \\
\hline \multicolumn{5}{|l|}{ 333-C0012E- } \\
\hline $3 X-4,28.5-31.5$ & 522.14 & 0.358 & 342 & 66 \\
\hline $8 \mathrm{H}-9,116.5-121.5$ & 71.19 & 0.226 & 1662 & 322 \\
\hline $16 \mathrm{H}-2,40.0-45.0$ & 138.04 & 0.197 & 903 & 175 \\
\hline $19 \mathrm{H}-3,47.5-52.5$ & 162.42 & 0.120 & 2744 & 531 \\
\hline $22 \mathrm{H}-7,56.0-61.0$ & 182.42 & 0.121 & 2427 & 470 \\
\hline $27 \mathrm{~T}-3,133.5-138.5$ & 222.28 & 0.182 & 431 & 83 \\
\hline
\end{tabular}

All nomenclature is defined in Table T1. 
Table T4. Summary of samples and tests performed.

\begin{tabular}{|c|c|c|c|c|c|c|}
\hline Core, section & $\begin{array}{c}\text { Depth } \\
\text { CSF-B (m) }\end{array}$ & $\begin{array}{c}\text { Lithologic } \\
\text { unit }\end{array}$ & $\begin{array}{c}\text { CRS } \\
\text { consolidation }\end{array}$ & $\begin{array}{l}\text { Grain } \\
\text { size }\end{array}$ & $\begin{array}{l}\text { Specific } \\
\text { surface }\end{array}$ & MICP \\
\hline \multicolumn{7}{|l|}{ 333-C0011C- } \\
\hline \multicolumn{7}{|l|}{ 333-C0011D- } \\
\hline $4 \mathrm{H}-1$ & 49.34 & IA & $x$ & $x$ & $x$ & \\
\hline $5 \mathrm{H}-7$ & 63.43 & IA & $x$ & $x$ & $x$ & \\
\hline $7 \mathrm{H}-5$ & 76.58 & IA & $x$ & $x$ & $x$ & \\
\hline $10 \mathrm{H}-1$ & 91.18 & IA & $x$ & $x$ & $x$ & \\
\hline $12 \mathrm{H}-8$ & 117.43 & IA & $x$ & $x$ & $x$ & \\
\hline $15 \mathrm{H}-8$ & 142.19 & IA & $x$ & $x$ & $x$ & $x$ \\
\hline $18 \mathrm{H}-9$ & 167.21 & IA & $x$ & $x$ & $x$ & \\
\hline $21 \mathrm{H}-5$ & 182.88 & IA & $x$ & $x$ & $x$ & $x$ \\
\hline $29 X-3$ & 222.42 & IA & $x$ & $x$ & $x$ & $x$ \\
\hline $36 X-2$ & 268.17 & IB & $x$ & $x$ & $x$ & \\
\hline $40 X-1$ & 301.71 & IB & $x$ & $x$ & $x$ & $x$ \\
\hline $44 X-1$ & 334.52 & IB & $x$ & $x$ & $x$ & \\
\hline $49 X-4$ & 363.00 & II & $x$ & $x$ & $x$ & \\
\hline \multicolumn{7}{|l|}{ 333-C0012C- } \\
\hline $3 \mathrm{H}-6$ & 21.81 & IA & $x$ & $x$ & $x$ & $x$ \\
\hline $6 \mathrm{H}-8$ & 51.30 & IA & $x$ & $x$ & $x$ & \\
\hline $9 \mathrm{H}-1$ & 70.27 & IA & $x$ & $x$ & $x$ & $x$ \\
\hline $10 \mathrm{H}-9$ & 85.84 & IB & $x$ & $x$ & $x$ & $x$ \\
\hline $13 \mathrm{H}-1$ & 102.34 & IB & $x$ & $x$ & $x$ & \\
\hline \multicolumn{7}{|l|}{ 333-C0012D- } \\
\hline $3 \mathrm{H}-6$ & 133.21 & IC & $x$ & $x$ & $x$ & \\
\hline $7 \mathrm{H}-5$ & 156.43 & II & $x$ & $x$ & $x$ & $x$ \\
\hline \multicolumn{7}{|l|}{ 333-C0012E- } \\
\hline $3 X-4$ & 522.14 & $\mathrm{VI}$ & $x$ & $x$ & $x$ & $x$ \\
\hline $3 X-4$ & 522.20 & VI & $x$ & & & \\
\hline \multicolumn{7}{|l|}{ 333-C0018A- } \\
\hline $5 \mathrm{H}-1$ & 35.45 & IAii & $x$ & $x$ & $x$ & \\
\hline $8 \mathrm{H}-9$ & 71.19 & IAiii & $x$ & $x$ & $x$ & $x$ \\
\hline $12 \mathrm{H}-9$ & 107.54 & IAiii & $x$ & $x$ & $x$ & \\
\hline $16 \mathrm{H}-2$ & 138.04 & IAiii (MTD 6) & $x$ & $x$ & $x$ & $x$ \\
\hline $19 \mathrm{H}-3$ & 162.42 & IAiii (MTD 6) & $x$ & $x$ & $x$ & \\
\hline $22 \mathrm{H}-7$ & 182.42 & IAiii (MTD 6) & $x$ & $x$ & $x$ & $x$ \\
\hline $27 \mathrm{~T}-3$ & 222.28 & $\mathrm{IB}$ & $x$ & $x$ & $x$ & $x$ \\
\hline $36 X-2$ & 305.58 & IB & $x$ & $x$ & $x$ & \\
\hline
\end{tabular}

CRS = constant-rate-of-strain. MICP = mercury injection capillary pressure. MTD = mass transport deposit. All nomenclature is defined in Table T1. 